\title{
Ribosomal Ribonucleic Acid Cistron Similarities and Deoxyribonucleic Acid Homologies of Neisseria, Kingella, Eikenella, Simonsiella, Alysiella, and Centers for Disease Control Groups EF-4 and M-5 in the Emended Family Neisseriaceae
}

\author{
R. ROSSAU,${ }^{1}+$ G. VANDENBUSSCHE,${ }^{1}$ S. THIELEMANS,${ }^{1}$ P. SEGERS, ${ }^{1}$ H. GROSCH, ${ }^{2}$ E. GÖTHE, ${ }^{2}$ \\ W. MANNHEIM, ${ }^{2}$ AND J. DE LEY ${ }^{1 *}$ \\ Laboratorium voor Microbiologie en microbiële Genetica, Rijksuniversiteit, Ledeganckstraat 35, B-9000 Gent, Belgium, ${ }^{1}$ \\ and Zentrum für Hygiene und medizinische Mikrobiologie, Klinikum der Philipps-Universität, D-3550 Marburg-Lahn, \\ Federal Republic of Germany ${ }^{2}$
}

\begin{abstract}
We detected distinct taxonomic relationships among the true Neisseria species, Kingella kingae, Kingella denitrificans, Eikenella corrodens, all Simonsiella species, the type strain of Alysiella filiformis, and members of Centers for Disease Control groups EF-4 and M-5. All these taxa constitute one large separate cluster having high levels of ribosomal ribonucleic acid cistron similarity (thermal denaturation temperature range, 74 to $81^{\circ} \mathrm{C}$ ) in ribosomal ribonucleic acid superfamily III. There are at least four subbranches. We found high deoxyribonucleic acid (DNA)-DNA homology values between Neisseria gonorrhoeae and some other true Neisseria species and within the following species: Simonsiella muelleri, Simonsiella crassa, Simonsiella steedae, Kingella denitrificans, and Eikenella corrodens. All of the members of this large cluster have genome base compositions in the range from 42.8 to $57.7 \mathrm{~mol} \%$ guanine plus cytosine. The molecular complexities of the genomic DNAs are $2.2 \times 10^{9}$ to $2.7 \times 10^{9}$ for Simonsiella and Alysiella species and $1.4 \times 10^{9}$ to $1.8 \times 10^{9}$ for the other members of this large cluster. We formally propose that this large cluster represents the emended family Neisseriaceae containing the following genera and groups: Neisseria, Kingella (not the generically misnamed Kingella indologenes), Eikenella, Simonsiella, Alysiella (not some misnamed strains), and Centers for Disease Control groups EF-4 and M-5. The genera and subgenera Acinetobacter, Moraxella, Branhamella, Psychrobacter, the false neisseriae, and Kingella indologenes should be removed from the Neisseriaceae, as they belong to superfamilies I and II.
\end{abstract}

In previous reports $(48,53)$ some of us showed that the bacterial family Neisseriaceae, as described in Bergey's Manual of Systematic Bacteriology (2), cannot maintain its present set of taxa and should be redefined. The genera Acinetobacter and Moraxella, including Branhamella catarrhalis, the false neisseriae ([Neisseria] ovis, [Neisseria] caviae, and [Neisseria] cuniculi), and the species [Kingella] indologenes should be removed from the Neisseriaceae, leaving only the true Neisseria species and two Kingella species (Kingella kingae and Kingella denitrificans) as unequivocal members of this family. Throughout this paper we use brackets to indicate generic misnomers (according to our findings) for organisms whose correct generic names are not yet known. Psychrobacter immobilis, which was recently included in the Neisseriaceae (36), is also not a member of this family (R. Rossau, M. Gillis, et al., manuscript in preparation).

Screening of a great variety of bacterial taxa of uncertain affiliation by using deoxyribonucleic acid (DNA)-ribosomal ribonucleic acid ( $\mathrm{R}$ RA) hybridization revealed that Eikenella corrodens, Simonsiella species, Alysiella species, and members of Centers for Disease Control (CDC) groups M-5, EF-4a, and EF-4b are close genetic relatives of the true Neisseria species. In this study we examined the phylogenetic interrelationships among these taxa and several other gram-negative bacteria.

\footnotetext{
* Corresponding author.

$\dagger$ Present address: N.V. Innogenetics, B-2000 Antwerpen, Belgium.
}

\section{MATERIALS AND METHODS}

Bacterial strains and media. Most of the strains which we used are listed in Table 1; a few more strains are listed in Table 2. These organisms were grown as described by Rossau et al. (48). The CDC group M-5 strains and the Alysiella filiformis type strain were grown on heart infusion (Difco Laboratories, Detroit, Mich.) agar in Roux flasks at $33^{\circ} \mathrm{C}$. The organisms mentioned below were grown in $500-\mathrm{ml}$ batches in 2-liter Fernbach flasks which were moderately aerated on a gyratory shaker at $36^{\circ} \mathrm{C}$. Eikenella corrodens was propagated in Mueller-Hinton broth (Oxoid Ltd., London, United Kingdom) supplemented with $25 \mu \mathrm{g}$ of hemin per $\mathrm{ml}$ (hemin chloride [Fluka Ag., Buchs, Switzerland]; $22 \times$ concentrated stock solution in $4 \%$ [vol/vol] triethanolamine [E. Merck AG, Darmstadt, Federal Republic of Germany], sterilized by filtration) and with Vitox (Oxoid). CDC group EF-4 strains were grown in tryptic soy broth (Difco) supplemented with $0.5 \%$ (wt/vol) yeast extract (Oxoid) that was sterilized by filtration, and Simonsiella and Alysiella strains were grown in tryptic soy broth supplemented with $2 \%(\mathrm{vol} / \mathrm{vol})$ horse serum (Oxoid) and Vitox (Oxoid). Mass cultures of Kingella kingae and Kingella denitrificans were grown in Schaedler broth (Bio-Mérieux, Charbonnières les Bains, France) or brain heart infusion broth (Oxoid) supplemented with $0.5 \%$ (wt/vol) yeast extract and $2 \%$ (vol/vol) horse serum as described above.

Isolation of DNA. DNA was isolated and purified by using the method of Marmur (40), with some modifications (48). Additional purification was achieved by preparative $\mathrm{CsCl}$ gradient centrifugation.

Fixation of single-stranded DNA on nitrocellulose mem- 
TABLE 1. List of most of the strains used, their DNA base compositions, and hybridization parameters of DNA-rRNA hybrids with various ${ }^{3} \mathrm{H}$-labeled rRNAs

\begin{tabular}{|c|c|c|c|c|c|c|c|c|c|c|}
\hline \multirow{3}{*}{$\begin{array}{l}\text { Sequence } \\
\text { no. }{ }^{a}\end{array}$} & \multirow{3}{*}{ DNA from ${ }^{b}:$} & \multirow{3}{*}{$\begin{array}{c}\mathrm{Mol} \% \\
\mathrm{G}+\mathrm{C}\end{array}$} & \multicolumn{8}{|c|}{ rRNA from: } \\
\hline & & & \multicolumn{2}{|c|}{$\begin{array}{c}\text { Neisseria } \\
\text { flavescens } \\
\text { ATCC } 13120^{\mathrm{T}}\end{array}$} & \multicolumn{2}{|c|}{$\begin{array}{c}\text { Simonsiella } \\
\text { muelleri ATCC } \\
29453^{\mathrm{T}}\end{array}$} & \multicolumn{2}{|c|}{$\begin{array}{c}\text { Eikenella } \\
\text { corrodens } \\
\text { NCTC } 10596^{\mathrm{T}}\end{array}$} & \multicolumn{2}{|c|}{$\begin{array}{c}\text { CDC group EF-4 } \\
\text { strain ATCC } \\
29858\end{array}$} \\
\hline & & & $\begin{array}{l}T_{m(e)} \\
\left({ }^{\circ} \mathrm{C}\right)\end{array}$ & $\begin{array}{c}\% \\
\text { RNA } \\
\text { binding }\end{array}$ & $\begin{array}{l}T_{m(e)} \\
\left({ }^{\circ} \mathrm{C}\right)\end{array}$ & $\begin{array}{c}\% \\
\text { RNA } \\
\text { binding }\end{array}$ & $\begin{array}{l}T_{m(e)} \\
\left({ }^{\circ} \mathrm{C}\right)\end{array}$ & $\begin{array}{c}\% \\
\text { RNA } \\
\text { binding }\end{array}$ & $\begin{array}{l}T_{m(e)} \\
\left({ }^{\circ} \mathrm{C}\right)\end{array}$ & $\begin{array}{c}\% \\
\text { RNA } \\
\text { binding }\end{array}$ \\
\hline 1 & Neisseria gonorrhoeae NCTC $8375^{\mathrm{T} c}$ & 53.2 & 77.6 & 0.25 & 73.7 & 0.13 & 75.3 & 0.07 & 73.9 & 0.10 \\
\hline 2 & Neisseria meningitidis NCTC $10025^{\mathrm{T}}$ & 52.8 & 78.5 & 0.29 & 75.9 & 0.11 & & & & \\
\hline 3 & Neisseria lactamica NCTC $10617^{\mathrm{T}}$ & 53.0 & 76.7 & 0.25 & 75.0 & 0.10 & 76.2 & 0.11 & 74.2 & 0.11 \\
\hline 4 & Neisseria lactamica NCTC 10616 & 53.8 & 77.5 & 0.24 & & & & & & \\
\hline 5 & Neisseria mucosa CIP $59.51^{\mathrm{T}}$ & 51.6 & 78.9 & 0.20 & 75.6 & 0.09 & 75.1 & 0.09 & 75.3 & 0.09 \\
\hline 6 & Neisseria subflava ATCC 10555 & 49.6 & 79.3 & 0.21 & & & & & & \\
\hline 7 & Neisseria flavescens ATCC $13120^{\mathrm{T}}$ & 49.6 & 80.6 & 0.24 & 75.4 & & & & 74.3 & \\
\hline 8 & Neisseria sicca NRL $30016^{\mathrm{T}}$ & 51.2 & 78.7 & 0.31 & & & 76.4 & & & \\
\hline 9 & Neisseria animalis NCTC $10212^{\mathrm{T}}$ & 51.3 & 76.2 & 0.24 & 75.3 & 0.09 & 75.5 & 0.09 & 75.5 & 0.11 \\
\hline 10 & Neisseria denitrificans ATCC $14686^{\mathrm{T}}$ & 56.2 & 76.5 & 0.19 & 75.6 & 0.10 & 75.6 & 0.09 & 74.8 & 0.11 \\
\hline 11 & Neisseria canis ATCC $14687^{\mathrm{T}}$ & 49.6 & 76.3 & 0.34 & 73.6 & & & & & \\
\hline 12 & $\begin{array}{l}\text { Neisseria elongata subsp. elongata NCTC } \\
10660^{\mathrm{T}}\end{array}$ & 53.1 & 75.9 & 0.20 & 75.8 & 0.09 & 76.1 & 0.10 & 75.5 & 0.10 \\
\hline 13 & $\begin{array}{l}\text { Neisseria elongata subsp. glycolytica } \\
\text { NCTC } 11050\end{array}$ & 54.8 & 76.7 & 0.18 & 75.3 & 0.10 & 76.4 & 0.08 & 74.6 & 0.10 \\
\hline 14 & Kingella kingae NCTC $10529^{\mathrm{T}}$ & 48.2 & 75.1 & 0.23 & 76.3 & 0.11 & 75.3 & 0.08 & 74.6 & 0.10 \\
\hline 15 & Kingella kingae NCTC 10746 & 47.4 & 75.8 & 0.22 & 76.1 & 0.12 & 75.4 & 0.08 & 74.6 & 0.12 \\
\hline 16 & Kingella denitrificans NCTC $10995^{\mathrm{T}}$ & 53.5 & 76.0 & 0.28 & & & 76.5 & 0.13 & & \\
\hline 17 & Kingella denitrificans NTCC 10997 & 55.9 & 76.4 & 0.26 & 74.9 & 0.16 & & & 75.7 & 0.12 \\
\hline 18 & [Kingella] indologenes NCTC $10717^{\mathrm{T}}$ & 48.2 & 63.3 & 0.17 & 62.5 & & & & & \\
\hline 19 & Eikenella corrodens NCTC $10596^{\mathrm{T}}$ & 56.4 & 75.1 & 0.36 & 74.2 & 0.11 & 80.0 & 0.13 & 75.4 & 0.11 \\
\hline 20 & Eikenella corrodens HIM 967-5 & 57.3 & 75.1 & 0.34 & 73.9 & 0.17 & 80.8 & 0.15 & 75.4 & 0.16 \\
\hline 21 & Eikenella corrodens HIM 815-5 & 54.6 & 74.6 & 0.26 & 73.2 & 0.11 & 80.2 & 0.11 & & \\
\hline 22 & Eikenella corrodens HIM 801-1 & 57.0 & 76.0 & 0.29 & & & 80.3 & 0.12 & & \\
\hline 23 & Eikenella corrodens HIM 930-8 & 53.6 & 75.5 & 0.26 & & & 78.9 & 0.11 & & \\
\hline 24 & Simonsiella crassa ATCC $15533^{\mathrm{T}}$ & 47.0 & 75.8 & 0.42 & 75.9 & 0.26 & 75.4 & 0.20 & 75.0 & 0.27 \\
\hline 25 & Simonsiella crassa ATCC 29447 & 45.1 & 75.2 & 0.28 & 75.1 & 0.24 & 75.5 & 0.16 & 74.9 & 0.18 \\
\hline 26 & Simonsiella steedae ATCC $27409^{\mathrm{T}}$ & 52.2 & 74.4 & 0.19 & 74.4 & 0.13 & 75.4 & 0.09 & 74.3 & 0.08 \\
\hline 27 & Simonsiella steedae ATCC 27410 & 51.5 & 75.5 & 0.20 & 75.3 & 0.14 & 76.0 & 0.08 & 75.0 & 0.11 \\
\hline 28 & Simonsiella steedae ATCC 27398 & 53.8 & 75.3 & 0.28 & 74.1 & 0.10 & & & & \\
\hline 29 & Simonsiella muelleri ATCC $29453^{\mathrm{T}}$ & 43.0 & 75.5 & 0.22 & 78.3 & 0.21 & 75.1 & 0.11 & 73.6 & 0.13 \\
\hline 30 & Simonsiella muelleri ATCC 29452 & 42.8 & 75.3 & 0.29 & 77.4 & 0.22 & 75.6 & 0.09 & 75.1 & 0.14 \\
\hline 31 & Simonsiella muelleri HIM 942-7 & 43.2 & 74.5 & 0.34 & 76.3 & 0.21 & 74.3 & 0.12 & 74.0 & 0.08 \\
\hline 32 & Simonsiella sp. strain ATCC 27381 & 57.7 & 75.5 & 0.29 & 74.5 & 0.13 & 75.1 & 0.09 & 74.1 & 0.14 \\
\hline 33 & Alysiella filiformis CCUG $3710^{\mathrm{T} d}$ & 48.7 & 75.0 & 0.29 & 75.2 & 0.12 & 75.2 & 0.10 & 74.8 & 0.11 \\
\hline 34 & [Alysiella] sp. strain ATCC 29468 & 40.5 & 63.1 & 0.18 & & & & & & \\
\hline 35 & [Alysiella] sp. strain HIM $1018-2$ & 45.0 & 65.2 & 0.11 & & & & & & \\
\hline 36 & CDC group EF-4a strain ATCC 29858 & 49.3 & & & & & 75.5 & 0.09 & 78.0 & 0.05 \\
\hline 37 & CDC group EF-4a strain CDC T-191/78 & 50.9 & 74.9 & 0.19 & 75.1 & 0.08 & & & 78.8 & 0.12 \\
\hline 38 & CDC group EF-4b strain CDC T-194/78 & 50.5 & 76.3 & 0.22 & 75.4 & 0.09 & 75.2 & 0.11 & 77.5 & 0.11 \\
\hline 39 & CDC group EF-4a strain HIM 892-1 & 50.2 & 74.9 & 0.16 & 75.0 & 0.10 & & & 77.3 & 0.12 \\
\hline 40 & CDC group EF-4a strain CCUG 17349 & 50.4 & 74.2 & 0.15 & 75.0 & 0.10 & & & 77.7 & 0.14 \\
\hline 41 & CDC group M-5 strain CDC B5522 & 51.3 & 76.3 & 0.26 & 75.4 & 0.10 & 76.4 & 0.11 & 76.9 & 0.11 \\
\hline 42 & CDC group M-5 strain CCUG 4007 & 52.0 & 76.3 & 0.26 & & & & & 76.4 & \\
\hline 43 & Chromobacterium violaceum NCTC $9757^{\mathrm{T}}$ & 67.2 & 70.9 & 0.31 & & & & & & \\
\hline 44 & Aquaspirillum dispar ATCC 27650 & 63 & 70.2 & 0.17 & & & & & & \\
\hline 45 & Janthinobacterium lividum NCTC $9796^{\mathrm{T}}$ & 65.5 & 67.9 & 0.16 & & & & & & \\
\hline 46 & Bordetella bronchiseptica NCTC 8761 & 69.5 & 67.4 & 0.08 & & & & & & \\
\hline 47 & Taylorella equigenitalis NCTC $11184^{\mathrm{T}}$ & 37.6 & 67.6 & 0.22 & & & & & & \\
\hline 48 & Oligella urethralis ATCC $17960^{\mathrm{T}}$ & 47.7 & 66.1 & 0.14 & & & & & & \\
\hline 49 & Oligella urethralis WM 6 & 47.2 & 66.2 & 0.16 & & & & & & \\
\hline 50 & Oligella urethralis WM 20 & 47.2 & 65.3 & 0.08 & & & & & & \\
\hline 51 & [Pseudomonas] woodsii NCPPB 2441 & & 68.2 & 0.08 & & & & & & \\
\hline 52 & [Pseudomonas] acidovorans ATCC $15668^{\mathrm{T}}$ & 66.6 & 66.0 & 0.07 & & & & & & \\
\hline 53 & Xylophilus ampelinus CNBP 2098 & 68.2 & 66.7 & 0.09 & & & & & & \\
\hline 54 & Moraxella bovis CCUG $2133^{\mathbf{T}}$ & 42.5 & 64.6 & 0.15 & & & & & & \\
\hline 55 & Moraxella (Branhamella) ovis ATCC $11227^{\mathrm{T}}$ & 45.9 & 65.1 & 0.16 & & & & & & \\
\hline 56 & $\begin{array}{l}\text { Moraxella (Branhamella) cuniculi ATCC } \\
1_{14688^{\mathrm{T}}}\end{array}$ & 46.1 & 61.7 & 0.12 & & & & & & \\
\hline
\end{tabular}


TABLE 1-Continued

\begin{tabular}{|c|c|c|c|c|c|c|c|c|c|c|}
\hline \multirow{3}{*}{$\begin{array}{l}\text { Sequence } \\
\text { no. }{ }^{a}\end{array}$} & \multirow{3}{*}{ DNA from ${ }^{b}:$} & \multirow{3}{*}{$\begin{array}{l}\mathrm{Mol} \% \\
\mathrm{G}+\mathrm{C}\end{array}$} & \multicolumn{8}{|c|}{ rRNA from: } \\
\hline & & & \multicolumn{2}{|c|}{$\begin{array}{c}\text { Neisseria } \\
\text { flavescens } \\
\text { ATCC } 13120^{\mathrm{T}}\end{array}$} & \multicolumn{2}{|c|}{$\begin{array}{l}\text { Simonsiella } \\
\text { muelleri ATCC } \\
29453^{\mathrm{T}}\end{array}$} & \multicolumn{2}{|c|}{$\begin{array}{c}\text { Eikenella } \\
\text { corrodens NCTC } \\
10596^{\mathrm{T}}\end{array}$} & \multicolumn{2}{|c|}{$\begin{array}{c}\text { CDC group EF-4 } \\
\text { strain ATCC } \\
29858\end{array}$} \\
\hline & & & $\begin{array}{l}T_{m(e)} \\
\left({ }^{\circ} \mathrm{C}\right)\end{array}$ & $\begin{array}{c}\% \\
\text { RNA } \\
\text { binding }\end{array}$ & $\begin{array}{l}T_{m(e)} \\
\left({ }^{\circ} \mathrm{C}\right)\end{array}$ & $\begin{array}{c}\% \\
\text { RNA } \\
\text { binding }\end{array}$ & $\begin{array}{l}T_{m(e)} \\
\left({ }^{\circ} \mathrm{C}\right)\end{array}$ & $\begin{array}{c}\% \\
\text { RNA } \\
\text { binding }\end{array}$ & $\begin{array}{l}T_{m(e)} \\
\left({ }^{\circ} \mathrm{C}\right)\end{array}$ & $\begin{array}{c}\% \\
\text { RNA } \\
\text { binding }\end{array}$ \\
\hline 57 & $\begin{array}{l}\text { Moraxella (Branhamella) caviae ATCC } \\
14659^{\mathrm{T}}\end{array}$ & 46.9 & 62.6 & 0.10 & & & & & & \\
\hline 58 & $\begin{array}{l}\text { Moraxella (Branhamella) catarrhalis } \\
\text { ATCC } 25238^{\mathrm{T}}\end{array}$ & 41.0 & 64.3 & 0.16 & & & & & & \\
\hline 59 & Acinetobacter calcoaceticus Torry 7-40 & 40.7 & 62.3 & 0.17 & & & & & & \\
\hline 60 & Escherichia coli B & 52.2 & 62.7 & 0.13 & & & & & & \\
\hline 61 & Rhizobium meliloti NZP 4009 & & 58.0 & 0.05 & & & & & & \\
\hline
\end{tabular}

${ }^{a}$ Sequence numbers are not strain numbers.

${ }^{b}$ Abbreviations: ATCC, American Type Culture Collection, Rockville, Md.; CCUG, Culture Collection of the University of Göteborg, Department of Clinical Bacteriology, University of Göteborg, Göteborg, Sweden; CDC, Centers for Disease Control, Atlanta, Ga.; CIP, Collection de l'Institut Pasteur, Paris, France; CNBP, Collection Nationale de Bactéries Phytopathogènes, Beaucouzé, France; HIM, Hygiene-Institut, Marburg, Federal Republic of Germany; NCPPB, National Collection of Plant Pathogenic Bacteria, Plant Pathology Laboratory, Harpenden, United Kingdom; NCTC, National Collection of Type Cultures, Central Public Health Laboratory, London, United Kingdom; NRL, Neisseria Reference Laboratory, Harborview Medical Center, Seattle, Wash.; NZP, Applied Biochemistry Division, Department of Scientific and Industrial Research, Palmerston North, New Zealand.

'Most values were taken from reference 48; the other values were determined in our laboratories, except for the Aquaspirilum dispar value, which was taken from reference 29 .

${ }^{d}$ This organism was also received separately as strain ATCC $15532^{\mathrm{T}}$ and as strain HIM $929-5^{\mathrm{T}}$; the same results were obtained

brane filters and determination of the amount of DNA fixed. High-molecular-weight denatured DNA was filter fixed as described by Gillis and De Ley (21). The amount of DNA fixed on a filter was determined by the method of Richards (44).

DNA base composition. The average moles percent guanine plus cytosine $(\mathrm{G}+\mathrm{C})$ of DNAs were determined spectropho- tometrically by using the method of De Ley and Van Muylem (13) and the equation of De Ley (7).

DNA-DNA hybridizations. The degree of DNA binding $(D)$, expressed as a percentage, was calculated from the initial renaturation rates by using the method of De Ley et al. (9); this value was a quantitative measure of the level of homology between the DNAs of a pair of strains. A model

TABLE 2. Hybridization parameters of the hybrids between DNAs from strains in the Neisseriaceae rRNA cluster and some misidentified strains and radioactively labeled rRNAs from various reference strains from different rRNA branches ${ }^{a}$

\begin{tabular}{|c|c|c|c|}
\hline DNA from: & rRNA from: & $T_{m(e)}\left({ }^{\circ} \mathrm{C}\right)$ & $\begin{array}{c}\% \text { rRNA } \\
\text { binding }\end{array}$ \\
\hline Neisseria meningitidis NCTC $10025^{\mathrm{T}}$ & Moraxella lacunata ATCC 17952 & 63.0 & 0.10 \\
\hline Neisseria mucosa CIP $59.51^{\mathrm{T}}$ & Moraxella lacunata ATCC 17952 & 64.6 & 0.13 \\
\hline Neisseria mucosa CIP $59.51^{\mathrm{T}}$ & [Pseudomonas] solanacearum NCPPB $325^{\mathrm{T}}$ & 69.9 & 0.08 \\
\hline Kingella denitrificans NCTC $10995^{\mathrm{T}}$ & Moraxella lacunata ATCC 17952 & 64.5 & 0.16 \\
\hline Alysiella filiformis CCUG $3710^{\mathrm{T}}$ & Moraxella lacunata ATCC 17952 & 62.5 & 0.18 \\
\hline [Alysiella] sp. strain ATCC 29468 & Moraxella lacunata ATCC 17952 & 0.15 & \\
\hline [Alysiella] sp. strain ATCC 29468 & "Moraxella paraphenylpyruvica"' CCUG $2651 \mathrm{~A}^{b}$ & 73.2 & 0.06 \\
\hline [Alysiella] sp. strain ATCC 29468 & Brucella abortus ATCC $23448^{\mathrm{T}}$ & 58.4 & 0.11 \\
\hline [Alysiella] sp. strain ATCC 29468 & Cardiobacterium hominis ATCC $15826^{\mathrm{T}}$ & 63.5 & 0.12 \\
\hline [Alysiella] sp. strain HIM 1018-2 & Moraxella lacunata ATCC 17952 & 76.9 & 0.11 \\
\hline$[$ Alysiella] sp. strain HIM $1018-2$ & "Moraxella paraphenylpyruvica" CCUG 2651A & 73.6 & 0.05 \\
\hline [Alysiella] sp. strain HIM $1018-2$ & Oligella urethralis WM 6 & 58.9 & 0.06 \\
\hline [Alysiella] sp. strain HIM $1018-2$ & Cardiobacterium hominis ATCC $15826^{\mathrm{T}}$ & 64.1 & 0.08 \\
\hline [Kingella] indologenes NCTC $10717^{\mathrm{T}}$ & Cardiobacterium hominis ATCC $15826^{\mathrm{T}}$ & 73.6 & 0.15 \\
\hline [Kingella] indologenes NCTC 10883 & Cardiobacterium hominis ATCC $15826^{\mathrm{T}}$ & 74.5 & 0.15 \\
\hline Simonsiella crassa ATCC $15533^{\mathrm{T}}$ & Chromobacterium violaceum NCTC $9757^{\mathrm{T}}$ & 71.7 & 0.24 \\
\hline Eikenella corrodens NCTC $10596^{\mathrm{T}}$ & Alcaligenes faecalis NCIB $8156^{\mathrm{Tc}}$ & 66.4 & \\
\hline Eikenella corrodens NCTC $10596^{\mathrm{T}}$ & [Pseudomonas] solanacearum NCPPB $325^{\mathrm{T}}$ & 68.7 & 0.13 \\
\hline Eikenella corrodens NCTC $10596^{\mathrm{T}}$ & Escherichia coli $\mathbf{B}$ & 61.7 & 0.15 \\
\hline CDC group EF-4a strain CDC T-191/78 & Alcaligenes xylosoxidans subsp. denitrificans ATCC $15173^{\mathrm{T}}$ & 66.6 & 0.12 \\
\hline CDC group EF-4a strain CDC T-191/78 & [Alcaligenes] paradoxus ATCC $17713^{\mathrm{T}}$ & 66.2 & 0.15 \\
\hline CDC group EF-4a strain CDC T-191/78 & Acinetobacter calcoaceticus ATCC $23055^{\mathrm{T}}$ & 60.6 & 0.16 \\
\hline CDC group EF-4a strain CDC T-191/78 & Actinobacillus lignieresii NCTC $4189^{\mathrm{T}}$ & 64.1 & 0.16 \\
\hline CDC group EF-4b strain CDC T-194/78 & Alcaligenes xylosoxidans subsp. denitrificans ATCC $15173^{\mathrm{T}}$ & 66.3 & 0.11 \\
\hline CDC group EF-4b strain CDC T-194/78 & [Alcaligenes] paradoxus ATCC 17713 & 67.0 & 0.13 \\
\hline CDC group M-5 strain CDC B5522 & Chromobacterium violaceum NCTC $9757^{\mathrm{T}}$ & 71.9 & 0.18 \\
\hline
\end{tabular}

${ }^{a}$ Only results which have not yet been published by members of our research group are listed. For additional values see references 47,48, and 53 .

${ }^{b}$ Names in quotation marks have not been validated.

${ }^{c}$ NCIB, National Collection of Industrial Bacteria, Torry Research Station, Aberdeen, United Kingdom. For other abbreviations see Table 1, footnote $b$. 
TABLE 3. DNA-DNA hybridization results expressed as the degree of binding between highly related neisseriae

\begin{tabular}{|c|c|c|c|c|c|c|c|}
\hline \multirow[b]{2}{*}{ Strain } & \multicolumn{7}{|c|}{$D(\%)$} \\
\hline & 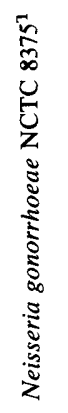 & 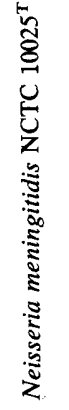 & 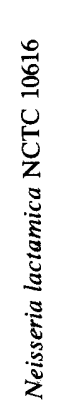 & 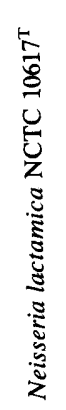 & 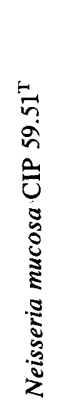 & 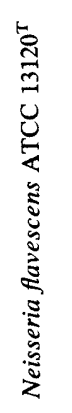 & 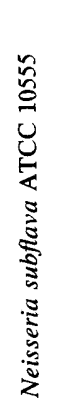 \\
\hline Neisseria gonorrhoeae NCTC $8375^{\mathrm{T}}$ & 100 & & & & & & \\
\hline Neisseria meningitidis NCTC $10025^{\mathrm{T}}$ & 74 & 100 & & & & & \\
\hline Neisseria lactamica NCTC 10616 & 58 & 56 & 100 & & & & \\
\hline Neisseria lactamica NCTC $10617^{\mathrm{T}}$ & & & 96 & 100 & & & \\
\hline Neisseria mucosa CIP $59.51^{\mathrm{T}}$ & 33 & 34 & 37 & & 100 & & \\
\hline Neisseria flavescens ATCC $13120^{\mathrm{T}}$ & & 31 & 34 & & 36 & 100 & \\
\hline Neisseria subflava ATCC 10555 & & & 29 & & 36 & 71 & 100 \\
\hline
\end{tabular}

2600 spectrophotometer (Gilford Instrument Laboratories, Inc., Oberlin, Ohio) equipped with a thermostatted cuvette chamber and a model 4225A graphic plotter (HewlettPackard Co., Palo Alto, Calif.) was used.

The DNA concentration in the cuvette was about 47 $\mu \mathrm{g} / \mathrm{ml}$, and the optimal renaturation temperature in $2 \times \mathrm{SSC}$ $(1 \times \mathrm{SSC}$ is $0.15 \mathrm{M} \mathrm{NaCl}$ plus $0.015 \mathrm{M}$ citric acid, $\mathrm{pH} 7.0)$ was calculated from equation 21 of De Ley et al. (9). $D$ values of about $30 \%$ or less were too high and should be disregarded.

Molecular complexities of the genomes. The molecular complexities (total molecular weights) were calculated from the initial renaturation rate constants by using the genome size of Escherichia coli $\mathrm{B}$ as a reference (20). The molecular complexities were calculated only for the DNAs used in the DNA-DNA hybridization experiments.

Preparation of ${ }^{3} \mathbf{H}$-labeled rRNAs. Labeled rRNAs from Neisseria flavescens ATCC $13120^{\mathrm{T}}$ ( $\mathrm{T}=$ type strain), Simonsiella muelleri ATCC $29453^{\mathrm{T}}$, Eikenella corrodens NCTC $10596^{\mathrm{T}}$, and CDC group EF-4 strain ATCC 29858 were prepared as described previously (47). The Neisseria flavescens type strain is a genotypic representative of the genus Neisseria (Tables 1 and 3).

DNA-rRNA hybridizations. The DNA-rRNA hybridizations were performed as described by De Ley and De Smedt (10), except that the volumes were reduced by a factor of 0.6 and the ribonuclease concentration was standardized as described by Van Landschoot et al. (53). The temperature at which one-half of a DNA-rRNA duplex is denatured [ $\left.T_{m(e)}\right]$ is a reliable measure of the genotypic relationships between organisms. The higher the $T_{m(e)}$, the higher the level of relatedness. The percentage of rRNA binding is the amount of rRNA (in micrograms) bound to $100 \mu \mathrm{g}$ of filter-fixed DNA after ribonuclease treatment. The latter parameter is not a measure of genetic relatedness but can often be used to differentiate between taxa with similar $T_{m(e)}$ values on rRNA cistron similarity maps.

\section{RESULTS}

DNA-rRNA hybridizations. Table 1 shows the parameters of the DNA-rRNA hybrids when we used ${ }^{3} \mathrm{H}$-labeled rRNAs from Neisseria flavescens ATCC $13120^{\mathrm{T}}$, Simonsiella muelleri ATCC $29453^{\mathrm{T}}$, Eikenella corrodens NCTC $10596^{\mathrm{T}}$, and CDC group EF-4 strain ATCC 29858. Various rRNA cistron relationships are shown in Fig. 1 through 6. In the upper part of Fig. 1, a cluster is delineated; this cluster includes strains of several Neisseria species (sequence no. 1 through 13 in Table 1), two Kingella species (sequence no. 14 through 17), three Simonsiella species (sequence no. 24 through 32 ), one Alysiella sp. strain (sequence no. 33), Eikenella corrodens (sequence no. 19 through 23), CDC group EF-4 (sequence no. 36 through 40 ), and CDC group M-5 (sequence no. 41 and 42). Other members of rRNA superfamily III (sequence no. 43 through 53) are located at $T_{m(e)}$ values between 66.0 and $70.9^{\circ} \mathrm{C}$ (Table 1 and Fig. 1 and 6 ). [Kingella] indologenes (sequence no. 18) and members of rRNA superfamily I (sequence no. 60), rRNA superfamily II (sequence no. 34, 35 , and 54 through 59), and rRNA superfamily IV (sequence no. 61) are all located in the area below a $T_{m(e)}$ value of $65.2^{\circ} \mathrm{C}$ on the rRNA similarity map (Fig. 1) and the $T_{m(e)}$ similarity dendrogram (Fig. 6).

Table 2 shows the hybridization parameters of the hybrids between DNAs from some members of the Neisseriaceae cluster, [Kingella] indologenes, and two strains misidentified as Alysiella sp. and rRNAs from reference strains belonging to other rRNA branches.

DNA-DNA hybridizations. The DNA-DNA hybridization results are shown in Tables 3 through 5 and Fig. 6 . The mean standard deviation for the separate hybridization results was $4 \% D$. Individual results are discussed below.

Molecular complexities of the genomes and mean moles percent $\mathbf{G}+\mathbf{C}$ values. The molecular complexities of the genomes of the strains belonging to Neisseria species, Kingella kingae, Kingella denitrificans, Eikenella corrodens, and CDC groups EF-4 and M-5 were fairly low $\left(1.4 \times 10^{9}\right.$ to $\left.1.8 \times 10^{9}\right)$; the Simonsiella species genomes had molecular complexities of $2.2 \times 10^{9}$ to $2.4 \times 10^{9}$, and the Alysiella filiformis genome had a molecular complexity of $2.7 \times 10^{9}$ (Table 6). The mean moles percent $\mathrm{G}+\mathrm{C}$ range in the Neisseriaceae cluster (sequence no. 1 through 42 except 


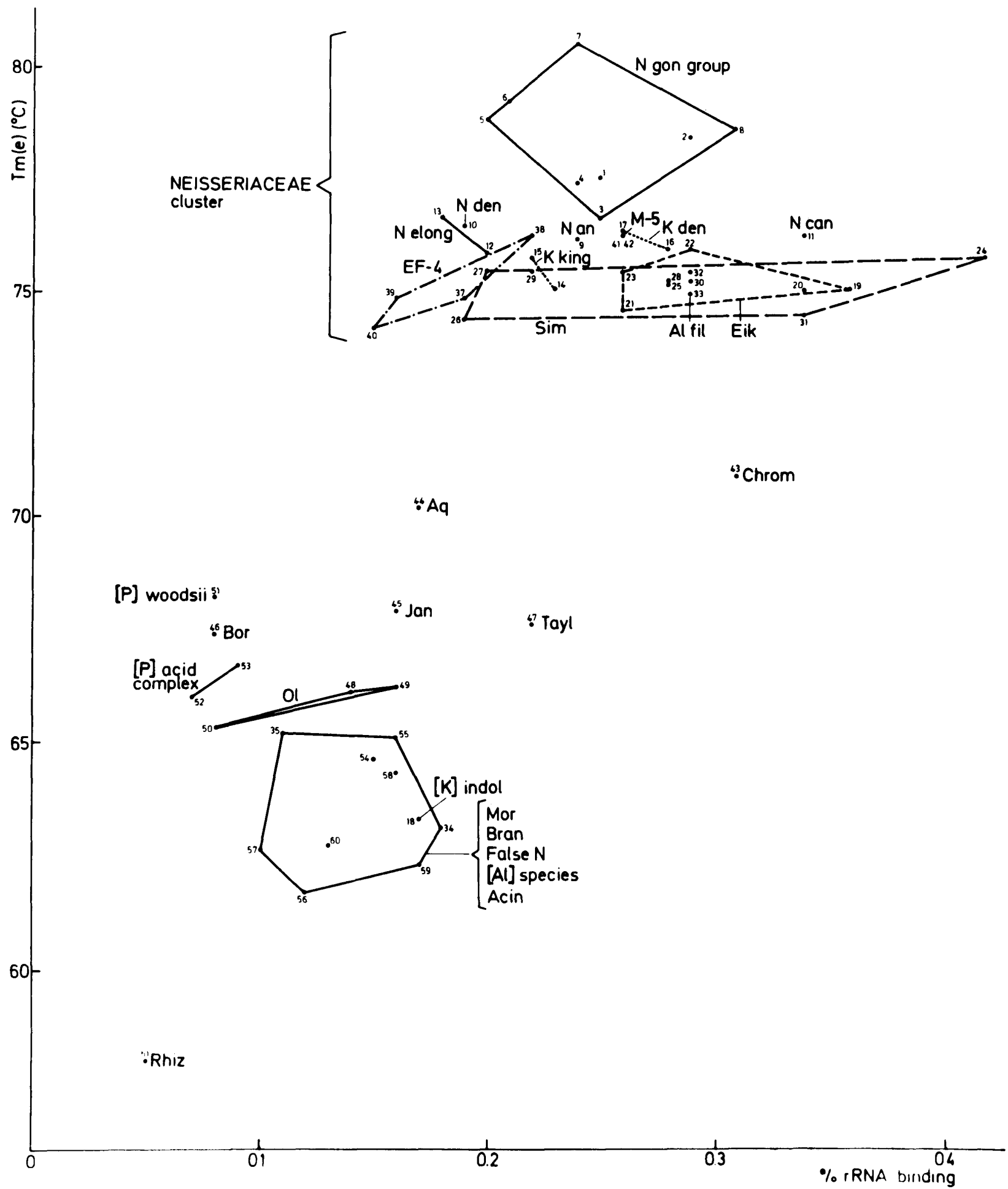

FIG. 1. rRNA similarity map of hybrids between ${ }^{3} \mathrm{H}$-labeled rRNA from Neisseria flavescens ATCC $13120^{\mathrm{T}}$ and DNAs from a variety of bacteria. Each strain is represented by its sequence number (see Table 1). Abbreviations: Acin, Acinetobacter; Al, Alysiella; [Al], misnamed Alysiella; Al fil, Alysiella filiformis; Aq, Aquaspirillum dispar; Bor, Bordetella; Bran, Branhamella; Chrom, Chromobacterium; E, Escherichia; EF-4, CDC group EF-4; Eik, Eikenella corrodens; Jan, Janthinobacterium; K, Kingella; K den, Kingella denitrificans; [K] indol, $[$ Kingella] indologenes; K king, Kingella kingae; N, Neisseria; $\mathrm{N}$ an, Neisseria animalis; $\mathrm{N}$ can, Neisseria canis; $\mathrm{N}$ den, Neisseria denitrificans; $\mathrm{N}$ elong, Neisseria elongata; $\mathrm{N}$ gon, Neisseria gonorrhoeae; Mor, Moraxella; M-5, CDC group M-5; Ol, Oligella; [P], misnamed Pseudomonas; [P] acid, [Pseudomonas] acidovorans; Rhiz, Rhizobium; Sim, Simonsiella; S cras, Simonsiella crassa; S muel, Simonsiella muelleri; S sp, Simonsiella species; S st, Simonsiella steedae; Tayl, Taylorella. 


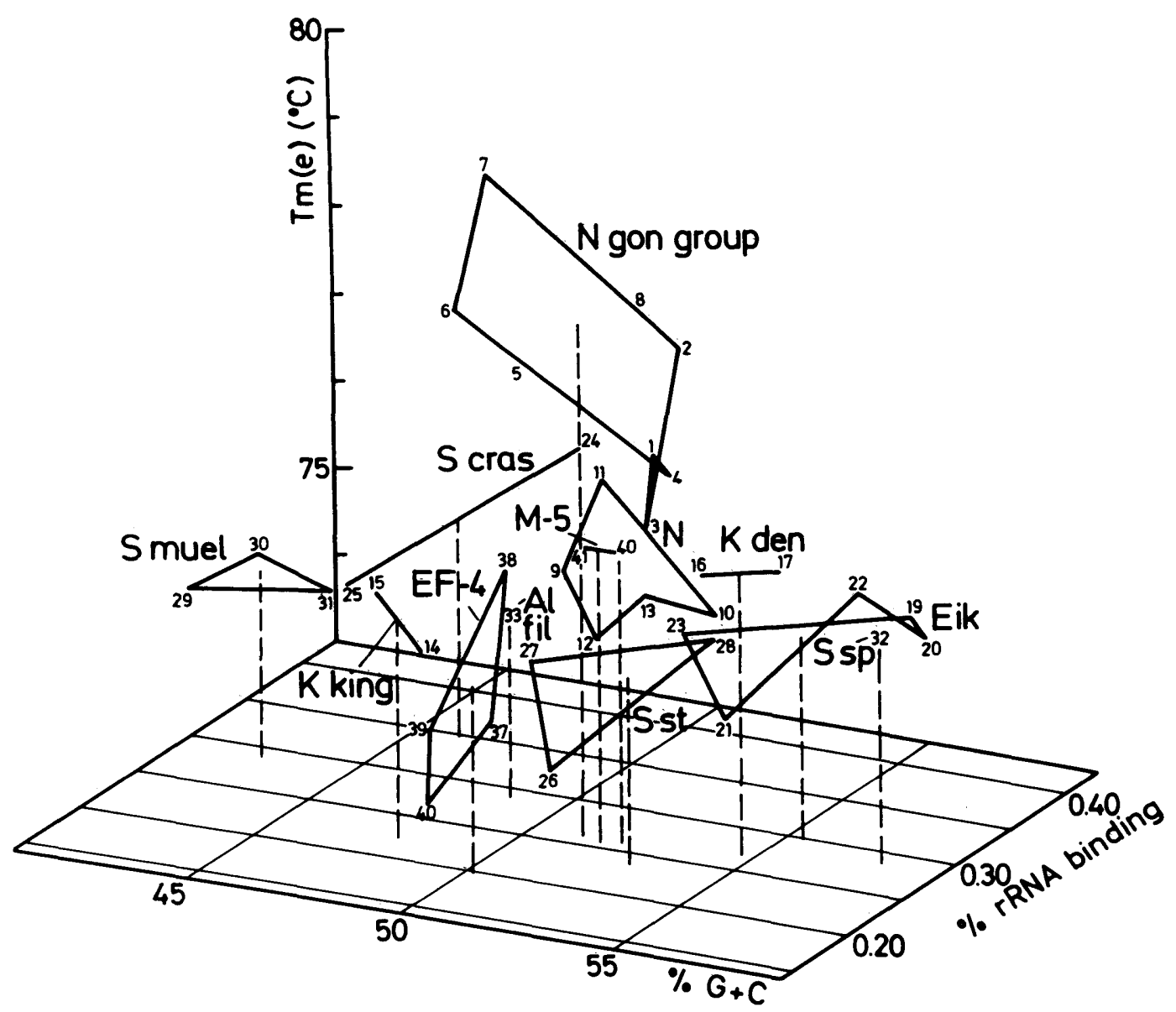

FIG. 2. Positions of the strains belonging to the Neisseriaceae cluster (Fig. 1) in a genotypic space defined by (i) the $T_{m(e)}$ values of the DNA-rRNA hybrids with Neisseria flavescens ATCC $13120^{\mathrm{T}}$ rRNA, (ii) the percentages of rRNA binding, and (iii) the mean moles percent $\mathrm{G}+\mathrm{C}$ values of the total genomes. For sequence numbers see Table 1. Sequences no. 9 through 13 indicate the positions of the named neisseriae other than those of the Neisseria gonorrhoeae group. For abbreviations see the legend to Fig. 1.

sequence no. 18,34 , and 35$)$ was rather broad $(42.8$ to 57.7 mol\%) (Table 1).

\section{DISCUSSION}

Because of the high evolutionary conservation of rRNA cistron sequences, rRNA similarities are very useful for determining more remote relationships among organisms. The rRNA cistron similarities of a great variety of gramnegative bacteria have been and are being studied extensively by members of the Gent research group, who are using a DNA-rRNA hybridization method $(8,10-12,14-16$, $21,47,48,53)$ in combination with other methods, such as moles percent $\mathrm{G}+\mathrm{C}$ and (occasionally) genome size determinations, DNA-DNA hybridization, numerical analysis of numerous phenotypic features; and protein gel electrophoresis. Based on the thermal stabilities of the DNA-rRNA hybrids [expressed as $T_{m(e)}$ in degrees Celsius], these organisms can be grouped together in at least six large groups, which we have called rRNA superfamilies I through VI (sensu De Ley [8]). Members of an rRNA superfamily usually group together in a $\Delta T_{m(e)}$ range that is, at most, about 12 to $14^{\circ} \mathrm{C}$ below the values of the homologous DNA-rRNA duplexes. Each rRNA superfamily probably corresponds to a taxonomic order. Each rRNA superfamily consists of quite a number of rRNA branches. An rRNA branch contains all of the organisms which are less than 12 to $14^{\circ} \mathrm{C} \Delta T_{m(e)}$ removed in DNA-rRNA hybridization experiments from the reference organism, which is a carefully selected, well-known, type or reference strain. A group of rRNA branches containing taxa which have phenotypic and genotypic similarities and which are at most 5 to $8^{\circ} \mathrm{C}$ $\Delta T_{m(e)}$ removed from each other we call an rRNA cluster. Some rRNA clusters or individual rRNA branches (depending on the number of labeled reference rRNAs available) correspond to a taxonomic family; examples are the Alcaligenes-Bordetella cluster (family Alcaligenaceae), the Rhizobium-Agrobacterium-Phyllobacterium cluster (family Rhizobiaceae), the Pasteurellaceae cluster, the Enterobacteriaceae rRNA branch, the Vibrionaceae rRNA branch, etc. Not all rRNA branches contain a taxonomic family; some contain only a genus or sometimes only a single species.

Each genotypic or phenotypic method has its own range of validity, and in most cases the methods, which cover approximately the same validity range, support each other. Taxonomic conclusions are often drawn by comparison with the taxonomic status of well-established taxa. The rRNA hybridization method is valid from about the order level to 


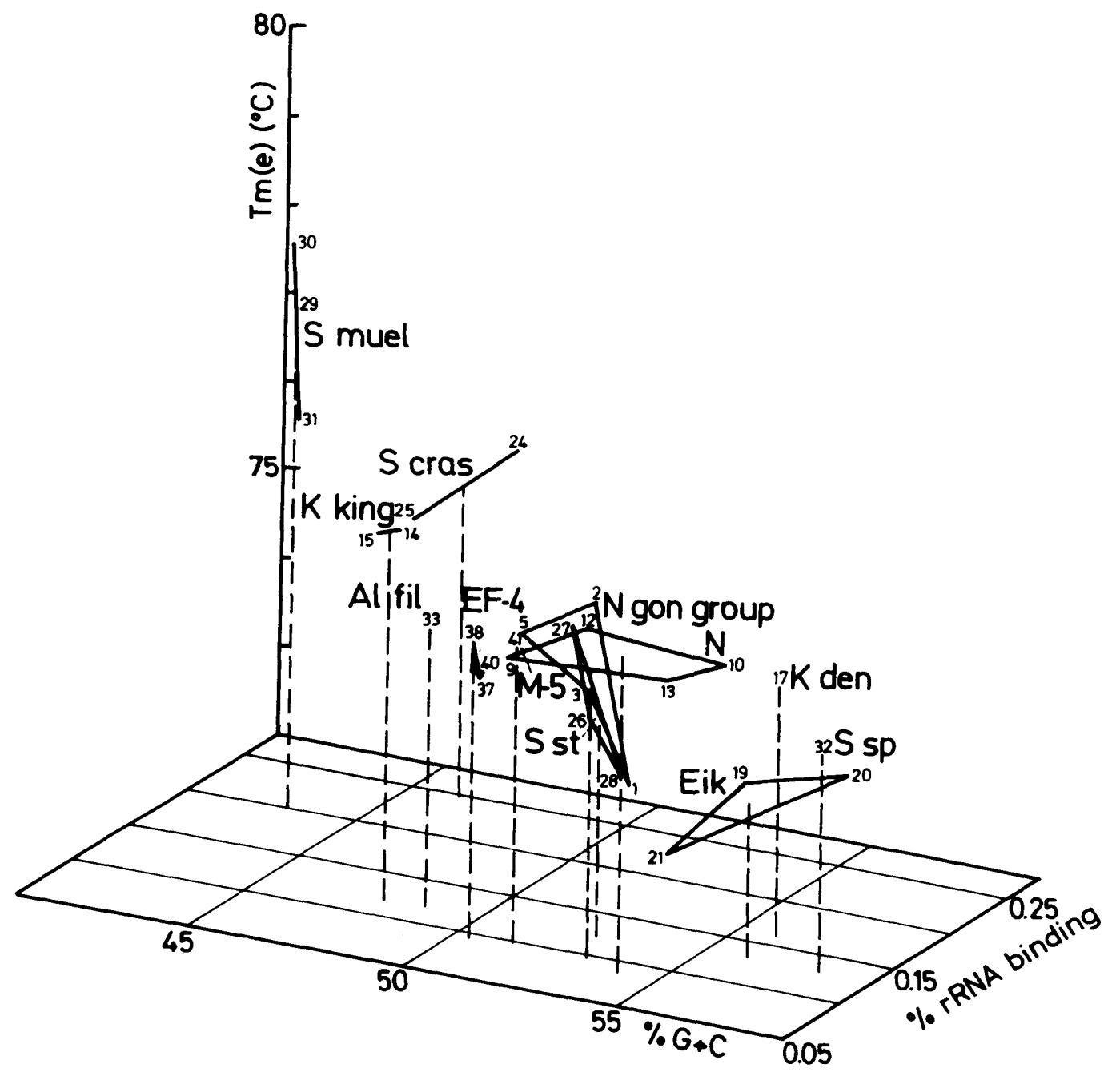

FIG. 3. Positions of the strains belonging to the Neisseriaceae cluster (Fig. 1) in a genotypic space defined by (i) the $T_{m(e)}$ values of the DNA-rRNA hybrids with Simonsiella muelleri ATCC $29453^{\mathrm{T}}$, (ii) the percentages of rRNA binding, and (iii) the mean moles percent G+C of the total genomes. For sequence numbers see Table 1. Sequences no. 9 through 13 indicate the positions of the neisseriae other than those of the Neisseria gonorrhoeae group. For abbreviations see the legend to Fig. 1.

about the subgenus or species level; rRNA cataloging, rRNA sequencing, and amino acid sequencing of cytochromes are valid from about the class level to about the genus or species level; DNA-DNA hybridization is valid between genera or within a genus depending on the heterogeneity of the taxon; numerical analysis of numerous phenotypic features $(>100$ features) is valid within or between genera; and numerical analysis of protein gel electropherograms is valid from the species level to the individual strain level. The taxonomic validity ranges of several other methods, such as fatty acid profiles, serology, zymograms, etc., are being examined.

Neisseriaceae cluster. We found that the true neisseriae, Kingella denitrificans, Kingella kingae, various Simonsiella species, Alysiella filiformis, Eikenella corrodens, and CDC groups EF-4 and M-5 are all closely interrelated in a $T_{m(e)}$ range from 73.2 to $80.8^{\circ} \mathrm{C}$ (Table 1 and Fig. 1 through 6 ). This cluster, which we refer to as the Neisseriaceae cluster, is definitely a member of rRNA superfamily III sensu De Ley (8), on which members of the Gent research group have already published extensively; the genera Chromobacterium (11) and Janthinobacterium (11), the generically misnamed [Pseudomonas] acidovorans and [Pseudomonas] solan- acearum clusters $(15,16)$, the family Alcaligenaceae (12), and the genera Oligella (47), Taylorella (47), and Derxia (14) are other members of rRNA superfamily III. The closest neighbors of the Neisseriaceae rRNA cluster are the genus Chromobacterium and some members of the genus Aquaspirillum at about $8^{\circ} \mathrm{C} \Delta T_{m(e)}$. All other members of rRNA superfamily III branch at an average $\Delta T_{m(e)}$ of approximately $12^{\circ} \mathrm{C}$. Organisms belonging to other rRNA superfamilies, such as the genera Moraxella and Acinetobacter, are at least $15^{\circ} \mathrm{C} \Delta T_{m(e)}$ away.

Each of the labeled reference rRNAs from Neisseria flavescens ATCC $13120^{\mathrm{T}}$, Simonsiella muelleri ATCC $29453^{\mathrm{T}}$, Eikenella corrodens NCTC $10596^{\mathrm{T}}$, and CDC group EF-4 strain ATCC 29858 is a member of a separate rRNA branch. These branches diverge at a $T_{m(e)}$ of $75.0^{\circ} \mathrm{C}$ (Fig. 6). There must be at least one additional rRNA branch in the Neisseriaceae cluster to accommodate Simonsiella crassa, Simonsiella steedae, Simonsiella sp., Alysiella filiformis, Kingella kingae, Kingella denitrificans, and some neisseriae.

Neisseria. The use of genetic transformation (1) and DNADNA hybridization (Table 3 and Fig. 6) $(18,23,27,37,45$, $46,55)$ within the true Neisseria revealed the existence of a 


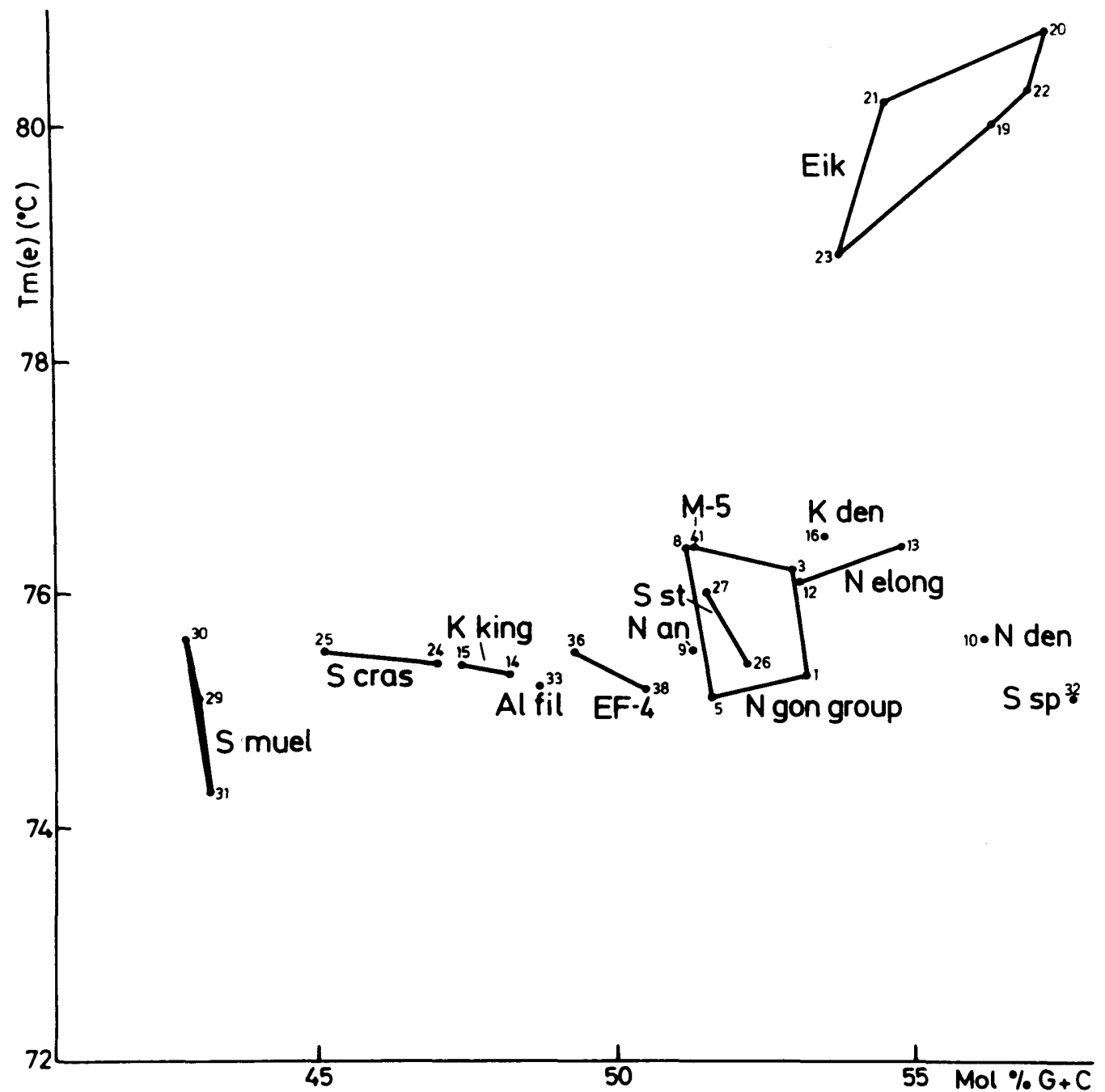

FIG. 4. Correlation between the mean moles percent $\mathrm{G}+\mathrm{C}$ values of the total genomes and the $T_{m(e)}$ values of hybrids between ${ }^{3} \mathrm{H}$-labeled rRNA from Eikenella corrodens NCTC $10596^{\mathrm{T}}$ and DNAs from strains of the Neisseriaceae cluster. For sequence numbers see Table 1. For abbreviations see the legend to Fig. 1.

large group (which we call the Neisseria gonorrhoeae group) with more than $30 \% D$. The same group was also detected by using DNA-rRNA hybridization (Fig. 1 and 2). This group is subdivided into at least three subgroups. One subgroup contains Neisseria flavescens, Neisseria subflava (including Neisseria perflava and Neisseria flava), and Neisseria sicca strains. A second subgroup contains Neisseria gonorrhoeae, Neisseria meningitidis, Neisseria lactamica, Neisseria polysaccharea, and Neisseria cinerea strains. Neisseria macacae also belongs in this subgroup (23), but its exact taxonomic position is not yet clear; therefore, it was not included in Fig. 6. The third subgroup contains Neisseria mucosa.

Within the genus Neisseria our DNA-DNA hybridization results (Tables 3 and 4) are in excellent agreement with those of Riou and his collaborators $(23,45)$. Although Hoke and Vedros (27) apparently used the same hybridization method that we used in our study, their results deviated considerably from ours. Perhaps they used DNA concentrations that were too high for such small genomes, yielding very high renaturation rates and the possibility of misinterpretation.

The levels of DNA homology between the members of the
Neisseria gonorrhoeae group and other members of the genus Neisseria are at or below the reliability limit of about $30 \% D$ (Table 4) $(46,55)$; the latter organisms are in the $T_{m(e)}$ range from 75.9 to $76.7^{\circ} \mathrm{C}$ versus rRNA from Neisseria flavescens (Table 1). The degree of binding $(D)$ between Neisseria elongata subsp. elongata NCTC $10660^{\mathrm{T}}$ and Neisseria elongata subsp. glycolytica NCTC 11050 was 59\%. Genetic transformation data demonstrated that Neisseria elongata is most probably a true Neisseria species. As far as we know, there is no genotypic evidence to support the inclusion of Neisseria denitrificans, Neisseria animalis, and Neisseria canis in the genus Neisseria. CDC group M-6 strains were not included in our genotypic studies. Phenotypically (49) and chemotaxonomically (41) these strains are very similar to Neisseria elongata. We cannot exclude the possibility that CDC group M-6 strains are nitrate-negative variants of Neisseria elongata, as suggested by Falsen (19).

Between Neisseria species and other representatives of the Neisseriaceae cluster no significant levels of DNA homology or higher levels of rRNA similarity were found (Tables 1, 4, and 5 and Fig. 1 through 6).

Kingella. The marginal relationship detected between Kin- 


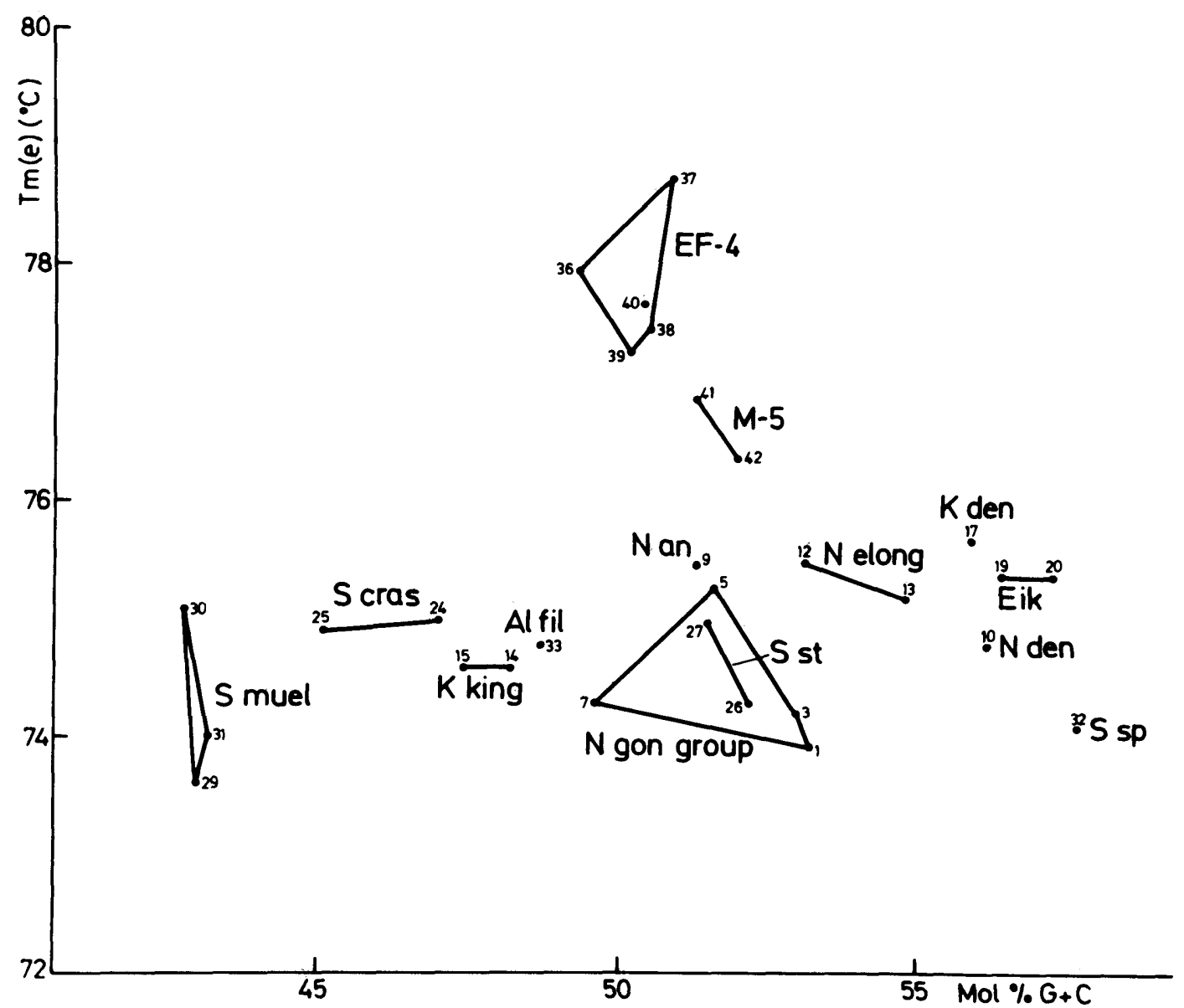

FIG. 5. Correlation between the mean moles percent $\mathrm{G}+\mathrm{C}$ values of the total genomes and the $T_{m(e)}$ values of hybrids between ${ }^{3} \mathrm{H}-1 \mathrm{labeled}$ rRNA from CDC group EF-4 strain ATCC 29858 and DNAs from strains of the Neisseriaceae cluster. For sequence numbers see Table 1. For abbreviations see the legend to Fig. 1.

gella kingae and Neisseria species by transformation experiments (3) and fatty acid analysis (32) was strengthened by our DNA-rRNA hybridization results (Table 1 and Fig. 1, 2, and 6). Kingella kingae and Kingella denitrificans are definitely part of the Neisseriaceae cluster. No DNA homology was found between Kingella kingae and Kingella denitrificans (Table 5). In all of our DNA-rRNA hybridizations both species were always separate (Fig. 2 through 5). Strains of both species showed generally negligibly low levels of DNA homology with all other strains belonging to the Neisseriaceae cluster. However, when Simonsiella muelleri rRNA was used, slightly higher $T_{m(e)}$ values were observed with DNAs from Kingella kingae strains than with DNAs from other organisms, suggesting a possible relationship between the two taxa. Some other criteria for relationship are the rather low moles percent $G+C$ values (Table 1), some similar phenotypic traits $(39,50)$, and similar fatty acid profiles with tetradecanoic acid as a prominent compound $(32,35)$. In other Simonsiella species tetradecanoic acid is also prominent (35). However, the genome complexity of Kingella kingae is only $60 \%$ that of Simonsiella muelleri (Table 6). Further clarification of the exact relationship between these taxa is needed. In view of their low moles percent $\mathrm{G}+\mathrm{C}$ values, Simonsiella crassa and Alysiella filiformis might also be considered possible relatives of Kingella kingae.

Rossau et al. showed previously that [Kingella] indolo- genes is not at all related to the other two Kingella species (Table 1) (48). A fairly high level of rRNA cistron similarity $\left[T_{m(e)}, 74.1^{\circ} \mathrm{C}\right.$ ] was found between [Kingella] indologenes and Cardiobacterium hominis (Table 2) (U. Rothenpieler, R. Mutters, W. Frederiksen, R. Rossau, P. Segers, J. De Ley, and W. Mannheim, Abstr. XIV Int. Congr. Microbiol., P. B4-8, p. 49, 1986). Both of these taxa are part of a separate rRNA branch which is remotely related to rRNA superfamilies I and II $\left[T_{m(e)}, 64.8^{\circ} \mathrm{C}\right](48 ; \mathrm{U}$. Rothenpieler et al., manuscript in preparation).

Simonsiella and the "Simonsiellaceae." The family "Simonsiellaceae" is composed of two genera of gliding bacteria, Simonsiella and Alysiella (38). These strictly aerobic, gramnegative bacteria are found in the oral cavities of animals and human beings and are considered to be nonpathogenic. They are easily recognized by their typical multicellular micromorphology. In the Reichenbach subdivision of gliding bacteria (43) the "Simonsiellaceae" were allocated to the order Nostocales within the cyanobacteriae. However, our DNArRNA hybridization results revealed considerable rRNA cistron similarities among representative strains of this family and Neisseria flavescens, Eikenella corrodens, and CDC group EF-4 [ $T_{m(e)}, 73.6$ to $\left.76.0^{\circ} \mathrm{C}\right]$ (Table 1 and Fig. 1 through 6). Thus, genotypically, the "Simonsiellaceae" are completely unrelated to the cyanobacteria and most other gliding bacteria.

DNA-rRNA hybridizations showed that the genus Simon- 


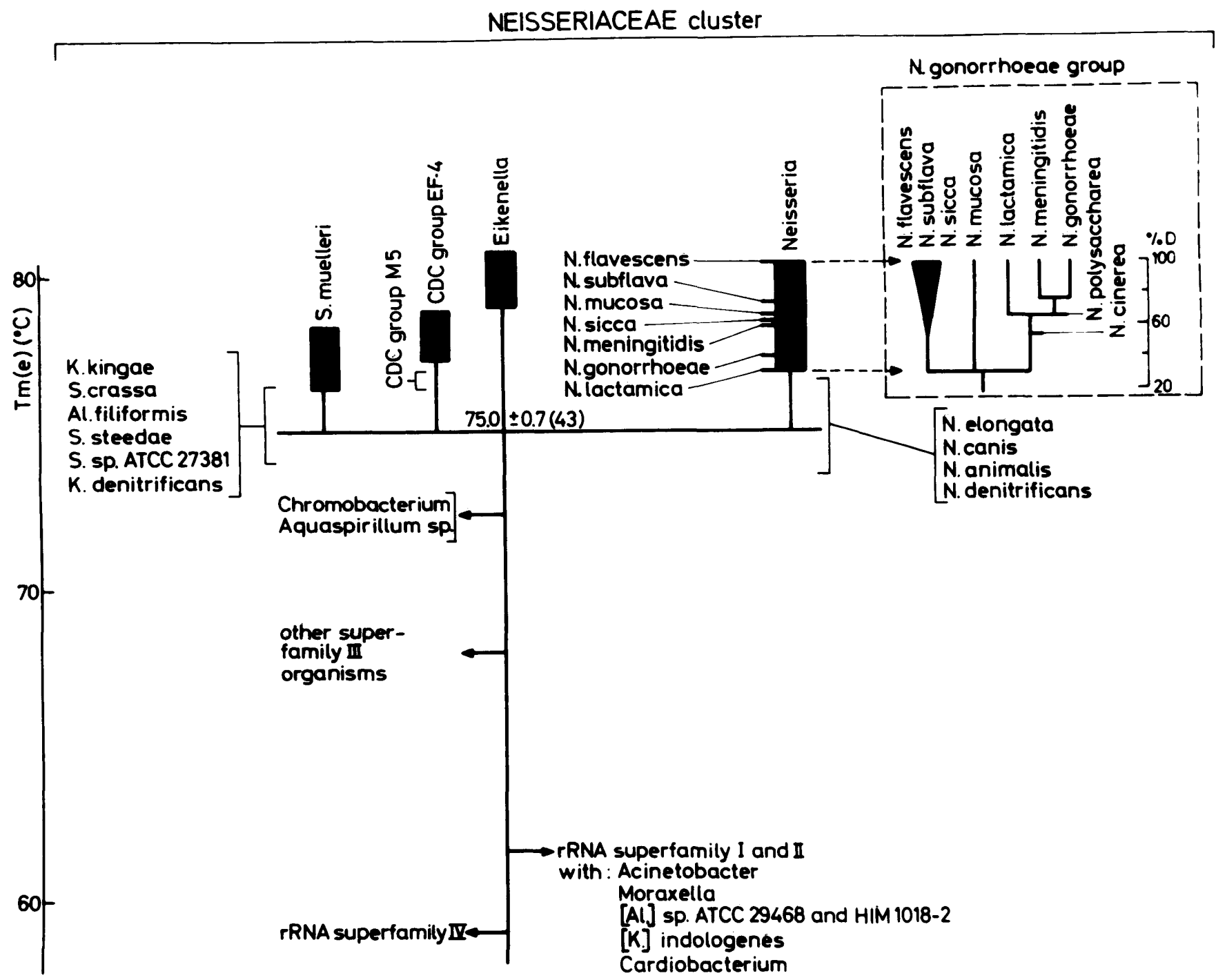

FIG. 6. Composite dendrogram showing the genotypic relationships of the taxa belonging to the Neisseriaceae cluster and other gram-negative bacteria. The rRNA cistron similarities are expressed as $T_{m(e)}$ values (in degrees Celsius) versus Simonsiella muelleri, CDC group EF-4, Eikenella corrodens, and Neisseria flavescens rRNAs. The solid bars indicate the ranges of $T_{m(e)}$ values for the clusters (see Fig. 1). The solid arrows indicate the average $T_{m(e)}$ values at the branching points; these values were taken from previous work by members of the Gent research group. The position of CDC group M-5 is not yet completely certain. The upper few degrees Celsius of a $T_{m(e)}$ dendrogram are not precise enough to represent the exact relationships between closely related taxa. More reliable relationships in the upper $3.5^{\circ} \mathrm{C}$ of the Neisseria gonorrhoeae group are shown in the insert DNA-DNA hybridization dendrogram (data from this study and references 23 and 45 ). In this case the upper $3.5^{\circ} \mathrm{C}$ of $T_{m(e)}$ corresponds to a range from about 30 to $100 \% \mathrm{D}$.

siella is genotypically heterogeneous and that its species are distributed all through the Neisseriaceae cluster (Fig. 2 through 5). The three strains of Simonsiella muelleri stand out as a small separate rRNA branch; both strains of Simonsiella crassa, three strains of Simonsiella steedae, and one unspecified Simonsiella strain constitute individual separate groups. The degrees of DNA interrelatedness among the different Simonsiella species were low. The levels of DNA relatedness of the different Simonsiella species with Kingella kingae, Kingella denitrificans, Neisseria gonorrhoeae, Eikenella corrodens, and CDC group EF-4 were equally low (Table 5).

Alysiella. Only one authentic member of the genus $A l$ ysiella, the type strain of Alysiella filiformis, is available from public culture collections. We received this organism from three different sources, as strain ATCC $15532^{\mathrm{T}}$, CCUG
$3710^{\mathrm{T}}$, or HIM $929-5^{\mathrm{T}}$. The results with the three strains were the same. This species, which was isolated from sheep, is also a member of the Neisseriaceae cluster (Table 1 and Fig. 1 through 6). It is separate from each of the four rRNA branches, and no DNA-DNA homologies could be demonstrated (Table 5).

Other isolates that were tentatively designated Alysiella sp. (e.g., strains ATCC 29468 and HIM 1018-2) were not significantly related to the type strain of Alysiella filiformis in terms of total DNA or DNA-rRNA hybridization (Tables 1 and 5 and Fig. 1 and 6). We established that strains ATCC 29468 and HIM 1018-2 have high levels of rRNA similarity $\left[T_{m(e)}, 76.4\right.$ and $76.9^{\circ} \mathrm{C}$, respectively] with Moraxella lacunata (Table 2), which clusters together with the genus Acinetobacter in rRNA superfamily II (48). It seems to be difficult, if not impossible, to discriminate false and true 
TABLE 4. DNA-DNA hybridization results expressed as the degree of binding between strains in the Neisseriaceae rRNA cluster but not belonging to the group formed by Neisseria gonorrhoeae and highly related neisseriae ${ }^{a}$

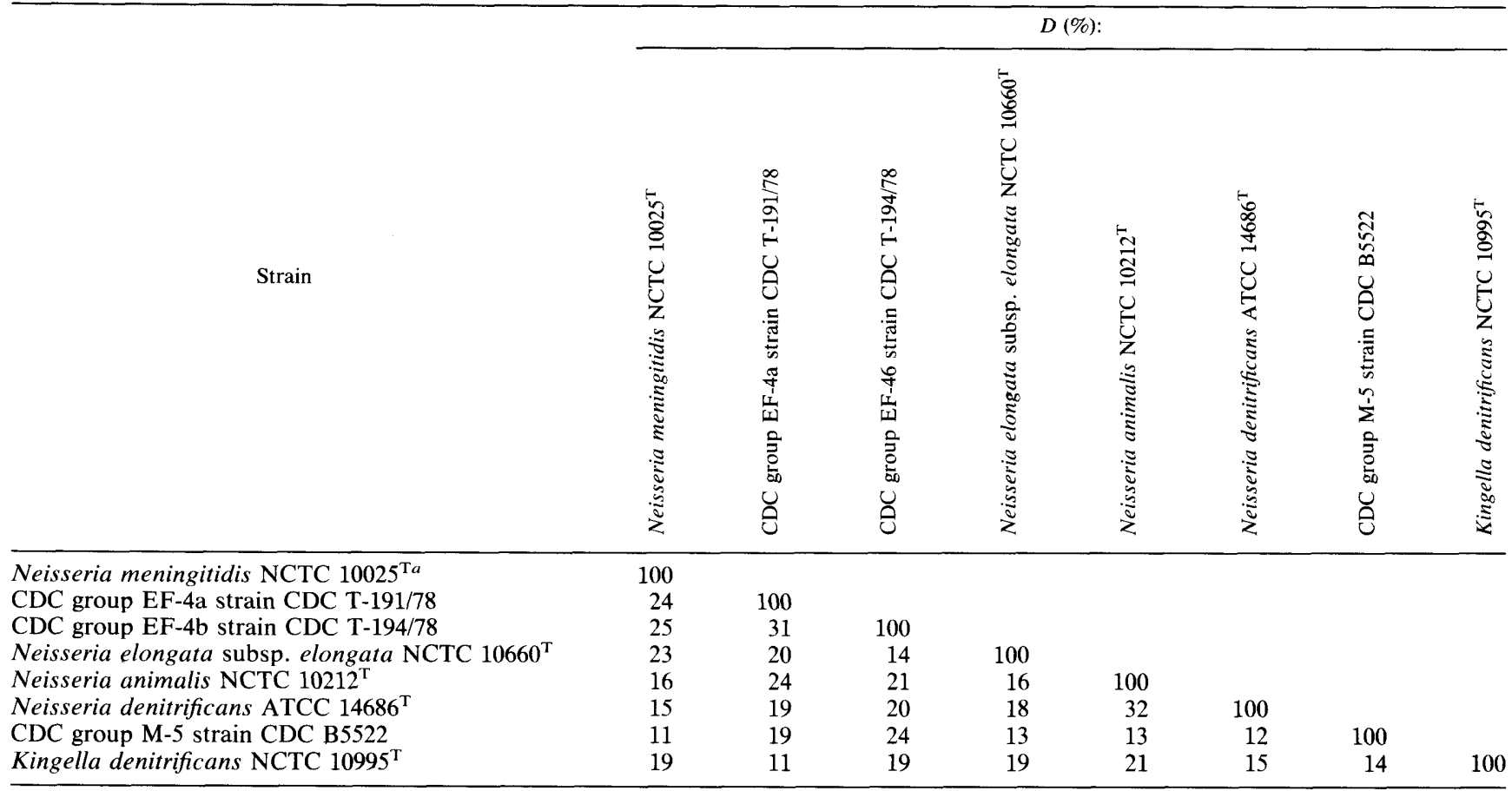

${ }^{a}$ See Table 3. Neisseria meningitidis NCTC $10025^{\mathrm{T}}$ was used as a representative of the group formed by Neisseria gonorrhoeae and highly related neisseriae.

Alysiella sp. strains by means of conventional phenotypic criteria. The statement (52) that the genera Simonsiella and Alysiella belong to different RNA subdivisions and that the latter is closest to the genus Acinetobacter was probably not based on an analysis of the type strain of Alysiella filiformis and should be revised.

Eikenella corrodens. Eikenella corrodens contains gramnegative, fastidious, facultatively anaerobic, nonmotile or twitching rods; these organisms pit agar surfaces and are biochemically rather inert. They grow well on blood agar in 5 to $10 \% \mathrm{CO}_{2}$ and their moles percent $\mathrm{G}+\mathrm{C}$ range from 56 to 58. Theșe organisms are normal human oral and intestinal inhabitants; many serious infections have been described, such as through human bites, abscesses, periodontal disease, osteomyelitis, etc.

Intraspecific DNA binding values obtained with a collection of strains that are phenotypically heterogeneous (with respect to hemolysis, nitrate reduction, hydrolases, oxidation of carbohydrates, colonial morphology, clinical significance) (Göthe et al., manuscript in preparation) essentially confirm the findings of Coykendall and Kaczmarek (5). These authors regard Eikenella corrodens as a molecularly homogeneous species with internal $D$ values of 70 to $100 \%$. The results of DNA-rRNA hybridization support this. Because of a positive oxidase reaction and a negative catalase reaction a possible relationship between Eikenella corrodens and Kingella kingae has been suggested (51). Serological cross-reactions between these two species have been observed (24). However, these taxa differ significantly in the moles percent $\mathrm{G}+\mathrm{C}$ of their DNAs $(8 \mathrm{~mol} \%)$ (Table 1$)$ and in their cellular fatty acid compositions $(32,42)$.

Some authors $(22,25,26,30)$ have suggested that the genus Eikenella belongs in the Brucellaceae. From our DNA-rRNA hybridization data (Table 1 and Fig. 1 through 6) we concluded that Eikenella corrodens is a member of the
Neisseriaceae cluster. From hybridizations with Eikenella corrodens rRNA (Table 1 and Fig. 4) and from DNA-DNA hybridization data (Table 5) we proved that Eikenella is a quite distinct genus in the family Neisseriaceae. Generally, Eikenella corrodens strains have higher octadecanoic acid contents ( 34 to $46 \%$ ) (42) than other members of the cluster.

CDC group EF-4. CDC group EF-4 consists of arginine dihydrolase-positive subgroup EF-4a and arginine dihydrolase-negative subgroup $\mathrm{EF}-4 \mathrm{~b}(4,28)$. These bacteria, which originally were thought to be related to the genus Pasteurella, are part of the oral flora of dogs and cats and are often isolated from infections resulting from dog and cat bites. The rRNA cistron similarities (Table 1 and Fig. 1 through 6) show that both CDC group EF-4 subgroups are part of the Neisseriaceae rRNA cluster as a separate rRNA branch; they appear to be most closely related to CDC group M-5 (Fig. 5). The recently detected phenotypic heterogeneity within CDC group EF-4 $(28,56)$ is strengthened by our DNA-DNA hybridization results; subgroup EF-4a and EF$4 \mathrm{~b}$ strains exhibit only a low degree of DNA binding $(31 \% \mathrm{D})$ (Table 4) and thus can be considered to be separate taxa. No significant DNA-DNA homology was detected between CDC group EF-4 members and other members of the cluster (Tables 4 and 5). The rRNA similarity with Neisseria species is supported by similarities in fatty acid patterns (6).

CDC group M-5. Members of CDC group M-5 also seem to be associated with infected dog bites $(4,49)$. They phenotypically resemble Moraxella species but are also similar in some respects to Neisseria elongata (49); therefore, they have sometimes been named "Neisseria parelongata" (19). The results of DNA-rRNA hybridizations with DNAs of CDC group M-5 strains indicate a relationship with $\mathrm{CDC}$ group EF-4 (Fig. 5). No significant DNA homology was found with any taxon tested (Table 4). The fatty acid profiles of CDC group M-5 strains essentially do not differ from those 
TABLE 5. Results of DNA-DNA hybridizations expressed as the degree of binding between type or reference strains of the genera Simonsiella, Alysiella, Kingella, Eikenella, and Neisseria and CDC group EF-4

\begin{tabular}{|c|c|c|c|c|c|c|c|c|c|c|c|c|c|c|c|c|c|c|c|}
\hline \multirow[b]{2}{*}{ Strain } & \multicolumn{19}{|c|}{$D(\%)$} \\
\hline & 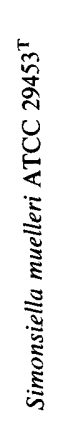 & 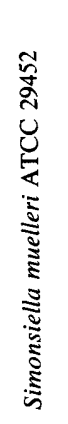 & 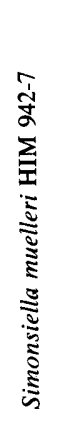 & 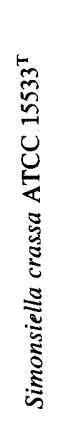 & 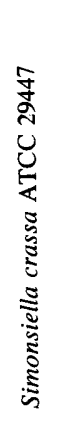 & 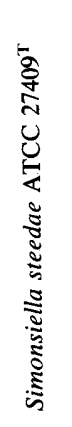 & 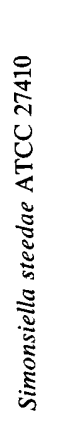 & 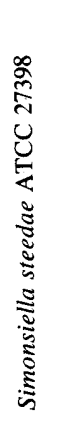 & 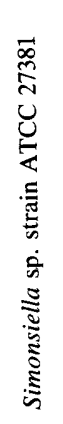 & 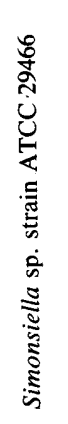 & 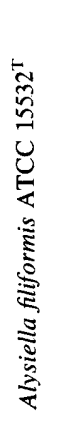 & 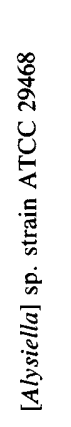 & 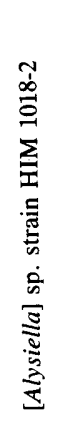 & 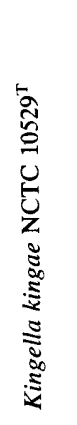 & 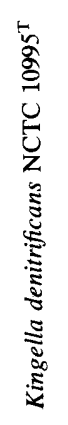 & 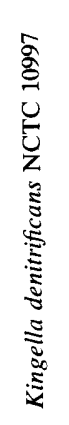 & 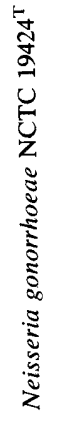 & 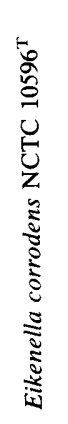 & 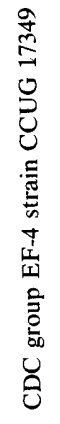 \\
\hline Simonsiella muelleri ATCC $29453^{\mathrm{T}}$ & 100 & & & & & & & & & & & & & & & & & & \\
\hline Simonsiella muelleri ATCC 29452 & 91 & 100 & & & & & & & & & & & & & & & & & \\
\hline Simonsiella muelleri HIM $942-7$ & 70 & 84 & 100 & & & & & & & & & & & & & & & & \\
\hline Simonsiella crassa ATCC $15533^{\mathrm{T}}$ & & & & 100 & & & & & & & & & & & & & & & \\
\hline Simonsiella crassa ATCC 29447 & & & & 80 & 100 & & & & & & & & & & & & & & \\
\hline $\begin{array}{l}\text { Simonsiella steedae ATCC } 27409^{\mathrm{T}} \\
\text { Simonsiella steedae ATCC } 27410\end{array}$ & 30 & & & 27 & & 100 & & & & & & & & & & & & & \\
\hline Simonsiella steedae ATCC 27410 & & & & & & 80 & 100 & & & & & & & & & & & & \\
\hline Simonsiella steedae ATCC 27398 & & & & & & 94 & 88 & 100 & & & & & & & & & & & \\
\hline Simonsiella sp. strain ATCC 27381 & 30 & & & 23 & & 40 & & & 100 & & & & & & & & & & \\
\hline Simonsiella sp. strain ATCC 29466 & & & & & & & & & 97 & 100 & & & & & & & & & \\
\hline Alysiella filiformis ATCC $15532^{\mathrm{T}}$ & 14 & & & 35 & & 13 & & & 29 & & 100 & & & & & & & & \\
\hline $\begin{array}{l}{[\text { Alysiella }] \text { sp. strain ATCC } 29468} \\
{[\text { Alysiella }] \text { sp. strain HIM } 1018-2}\end{array}$ & 24 & & & & & 27 & & & 30 & & $\begin{array}{l}31 \\
28\end{array}$ & 100 & 100 & & & & & & \\
\hline Kingella kingae NCTC $10529^{\mathrm{T}}$ & 28 & & & 33 & & 32 & & & 26 & & 19 & & & $100^{a}$ & & & & & \\
\hline Kingella denitrificans NCTC $10995^{\mathrm{T}}$ & 32 & & & 20 & & 21 & & & 31 & & 28 & & & $8^{a}$ & 100 & & & & \\
\hline Kingella denitrificans NCTC 10997 & & & & & & & & & & & & & & & 74 & 100 & & & \\
\hline $\begin{array}{l}\text { Neisseria gonorrhoeae ATCC } \\
19424^{\mathrm{T}}\end{array}$ & 28 & & & & & 34 & & & 32 & & 26 & & & & & & 100 & & \\
\hline Eikenella corrodens NCTC $10596^{\mathrm{T}}$ & 23 & & & 26 & & 33 & & & 30 & & 34 & & & 12 & 25 & & 28 & 100 & \\
\hline $\begin{array}{l}\text { CDC group EF-4 strain CCUG } \\
17349\end{array}$ & 15 & & & 25 & & 27 & & & 24 & & 0 & & & & & & & 34 & 100 \\
\hline
\end{tabular}

${ }^{a}$ Data from Rothenpieler et al. (manuscript in preparation).

of CDC group EF-4 strains $(6,34,41)$ and strains in the genus Neisseria (32). In contrast to the CDC group EF-4 strains, CDC group $\mathrm{M}-5$ strains are asaccharolytic and do not reduce nitrate $(49,56)$.

Taxonomic implications. The most recent officially proposed taxonomic composition of the family Neisseriaceae is that of $\mathrm{B} \phi \mathrm{vre}(2)$. In addition to the genus Neisseria, this family includes the genera Moraxella (with two subgenera, Moraxella and Branhamella), Acinetobacter, and Kingella. The genus Psychrobacter was added in 1986 (36). Our results from this study and from previous studies $(47,48,53)$ prove that the present family Neisseriaceae as such is not justified. It has to be emended by exclusion of the genera Acinetobacter, Moraxella (with its two subgenera, Moraxella and Branhamella), and Psychrobacter (Rossau et al., in preparation), which are members of rRNA superfamily II. The emended family Neisseriaceae has to correspond to our Neisseriaceae rRNA cluster, and it has to include the following genera and groups: true Neisseria, Kingella (not [Kingella] indologenes), Simonsiella, Alysiella, Eikenella, and CDC groups EF-4 and M-5. There is no justification for accepting the nonvalidated family "Simonsiellaceae," as it is a more recent proposal; both genera in this family should be included in the Neisseriaceae. The degree of genotypic homogeneity in the Neisseriaceae rRNA cluster $\left[\Delta T_{m(e)}\right.$ range, $6.4^{\circ} \mathrm{C}$ (Table 1)] is comparable to the degrees of homogeneity within some other genotypically well-defined bacterial families, such as the Alcaligenaceae (12) $\left[\Delta T_{m(e)}\right.$ range, $\left.6^{\circ} \mathrm{C}\right]$, the Acetobacteriaceae $(21)\left[\Delta T_{m(e)}\right.$ range, $\left.5^{\circ} \mathrm{C}\right]$, and the Enterobacteriaceae $\left[\Delta T_{m(e)}\right.$ range, $\left.9^{\circ} \mathrm{C}\right]$ (J. De Ley and $\mathrm{R}$. Tytgat, manuscript in preparation).

All of the data presented in this paper justify the proposal for the emended family Neisseriaceae. The description below was compiled from references $2,6,17,31,33,35,38$, $41,42,49,50,54,56$.

Description of the Neisseriaceae (Prévot 1933, 119 ${ }^{\mathrm{AL}}$ ) emend. Neisseriaceae (Neis.se.ri.a'ce.ae. M.L. fem. $\mathrm{n}$. Neisseria, type genus of the family; -aceae, ending to denote family; M.L. fem. pl. n. Neisseriaceae, the Neisseria family). Organisms are coccal, coccoid, or rod shaped, or they exhibit a multicellular micromorphology (Simonsiella and Alysiella). Gram-negative, with a tendency to resist decolorization. Endospores are not formed. Flagella are absent. Swimming motility is not observed, but there may be twitching or gliding motility. Capsules and fimbriae may be present. Aerobic, but some species also grow anaerobically (Kingella sp. and Eikenella corrodens). Chemoorganotrophic and mesophilic. Oxidase active; no indole production. Biochemically rather inert. Some species are nutritionally fastidious; some are saccharolytic. The main habitat is the mucosal surfaces of human beings and other mammals. Most species are opportunistic, but some are primary pathogens of humans. The fatty acid profiles of the taxa examined show the presence of saturated or monounsaturated non- 
TABLE 6. Molecular complexities of the genomes of strains (mostly type strains) belonging to the Neisseriaceae cluster

\begin{tabular}{|c|c|}
\hline Strain & $\begin{array}{c}\text { Genome mol } \\
\text { wt }\left(\times 10^{9}\right)\end{array}$ \\
\hline Neisseria gonorrhoeae NCTC $8375^{\mathrm{T}}$ & 1.5 \\
\hline Neisseria meningitidis NCTC $10025^{\mathrm{T}}$ & 1.4 \\
\hline Neisseria lactamica NCTC $10617^{T}$ & 1.5 \\
\hline Neisseria lactamica NCTC 10616 & 1.5 \\
\hline Neisseria mucosa CIP $59.51^{\mathrm{T}}$ & 1.5 \\
\hline Neisseria subflava ATCC 10555 & 1.8 \\
\hline Neisseria flavescens ATCC $13120^{\mathrm{T}}$ & 1.4 \\
\hline Neisseria animalis NCTC $10212^{\mathrm{T}}$ & 1.4 \\
\hline Neisseria denitrificans ATCC $14686^{\mathrm{T}}$ & 1.7 \\
\hline Neisseria elongata subsp. elongata NCTC $10660^{\mathrm{T}}$ & 1.7 \\
\hline Neisseria elongata subsp. glycolytica NCTC 11050 & 1.5 \\
\hline Kingella kingae NCTC $10529^{\mathrm{T}}$ & $1.4^{a}$ \\
\hline Kingella kingae NCTC 10746 & $1.8^{a}$ \\
\hline Kingella denitrificans NCTC $10995^{\mathrm{T}}$ & 1.5 \\
\hline Kingella denitrificans NCTC 10997 & 1.8 \\
\hline Eikenella corrodens NCTC $10596^{\mathrm{T}}$ & 1.7 \\
\hline Simonsiella crassa ATCC $15533^{\mathrm{T}}$ & 2.4 \\
\hline Simonsiella steedae ATCC $27409^{\mathrm{T}}$ & 2.2 \\
\hline Simonsiella muellerii ATCC $29453^{\mathrm{T}}$ & 2.3 \\
\hline Alysiella filiformis ATCC $15532^{\mathrm{T}}$ & 2.7 \\
\hline CDC group EF-4a strain CDC T-191/78 & 1.6 \\
\hline CDC group EF-4b strain CDC T-194/78 & 1.8 \\
\hline CDC group M-5 strain CDC B5522 & 1.6 \\
\hline
\end{tabular}

${ }^{a}$ U. Rothenpieler et al., personal communication.

branched fatty acids, predominantly with 14,16 , or 18 carbon atoms. Carbonic anhydrase is found in all of the taxa studied. Nearly all family members use ubiquinones as sole respiratory quinones.

$\mathrm{G}+\mathrm{C}$ range, 41 to $58 \mathrm{~mol} \%$ (determined mainly by the thermal denaturation method). Genome molecular complexity, $1.4 \times 10^{9}$ to $2.7 \times 10^{9}$. All taxa are found within a $\Delta T_{m(e)}$ range of $7.6^{\circ} \mathrm{C}$ (DNA-rRNA hybridization). The type genus is Neisseria Trevisan 1885, 105.

The following species are included at this time in the type genus (Fig. 6): Neisseria gonorrhoeae, Neisseria meningitidis, Neisseria lactamica, Neisseria sicca, Neisseria subflava (including Neisseria perflava and Neisseria flava), Neisseria flavescens, Neisseria mucosa, Neisseria macacae, Neisseria cinerea, Neisseria polysaccharea, Neisseria elongata, Neisseria canis, Neisseria animalis, and Neisseria denitrificans. The allocation of the last three species in this genus is not yet certain.

The following genera and other taxa are also included in this family (Fig. 6): Kingella Henriksen and Bøvre 1976, $449^{\mathrm{AL}}$ (excluding [Kingella] indologenes); Eikenella Jackson and Goodman 1972, $72^{\mathrm{AL}}$; Simonsiella Schmid 1922, 504 ${ }^{\mathrm{AL}}$; Alysiella Langeron 1923, $116^{\mathrm{AL}}$; and CDC groups EF-4 and M-5. The possible inclusion of the genus Chromobacterium and a few aquaspirilla (B. Pot, M. Gillis, C. Aerts, and J. De Ley, FEMS Symp. Evolution Prokaryotes, abstr. no. C8, 1984 ) in the Neisseriaceae [average $\Delta T_{m(e)}, 8$ to $9^{\circ} \mathrm{C}$ ] is uncertain. The interrelatedness of some of these taxa within the emended family requires further investigation.

\section{ACKNOWLEDGMENTS}

J.D.L. is indebted to the Fonds voor Geneeskundig Wetenschappelijk Onderzoek (Belgium) for research and personnel grants. W.M. and co-workers gratefully acknowledge a grant from the Deutsche Forschungsgemeinschaft (Federal Republic of Germany). R.R. is indebted to the Instituut tot Aanmoediging van het Wetenschappelijk Onderzoek in Nijverheid en Landbouw (Belgium) for a scholarship.
We are indebted to E. Falsen (Göteborg, Sweden) for the gift of strains.

\section{LITERATURE CITED}

1. Bøvre, K. 1980. Progress in classification and identification of Neisseriaceae based on genetic affinity, p. 55-72. In M. Goodfellow and R. G. Board (ed.), Microbiological classification and identification. Academic Press, Inc. (London), Ltd., London.

2. Bøvre, K. 1984. Family VIII. Neisseriaceae Prévot $1933,119^{\mathrm{AL}}$, p. 288-309. In N. R. Krieg and J. G. Holt (ed.), Bergey's manual of systematic bacteriology, vol. 1. The Williams \& Wilkins Co., Baltimore.

3. Bøvre, K., L. O. Froholm, S. D. Henriksen, and E. Holten. 1977. Relationship of Neisseria elongata subsp. glycolytica to other members of the family Neisseriaceae. Acta Pathol. Microbiol. Scand. Sect. B 85:18-26.

4. Clark, W. A., D. G. Hollis, R. E. Weaver, and P. Riley. 1984 Identification of unusual pathogenic Gram-negative aerobic and facultatively anaerobic bacteria, p. 144-147. Centers for Disease Control, Atlanta.

5. Coykendall, A. L., and F. S. Kaczmarek. 1980. DNA homologies among Eikenella corrodens strains. J. Periodontal Res. 15: 615-620.

6. Dees, S. B., J. Powell, C. W. Moss, D. G. Hollis, and R. E. Weaver. 1981. Cellular fatty acid composition of organisms frequently associated with human infections resulting from dog bites: Pasteurella multocida and groups EF-4, IIj, M-5, and DF-2. J. Clin. Microbiol. 14:612-616.

7. De Ley, J. 1970. Reexamination of the association between melting point, buoyant density, and chemical base composition of deoxyribonucleic acid. J. Bacteriol. 101:738-754.

8. De Ley, J. 1978. Modern methods in bacterial taxonomy: evaluation, application, prospects, p. 347-357. In Proceedings of the 4th International Conference on Plant Pathogenic Bacteria, Angers, vol. 1. Gibert-Clarey, Tours, France.

9. De Ley, J., H. Cattoir, and A. Reynaerts. 1970. The quantitative measurement of DNA hybridization from renaturation rates. Eur. J. Biochem. 12:133-142.

10. De Ley, J., and J. De Smedt. 1975. Improvements of the membrane filter method for DNA:rRNA hybridization. Antonie van Leeuwenhoek J. Microbiol. Serol. 41:287-308.

11. De Ley, J., P. Segers, and M. Gillis. 1978. Intra- and intergeneric similarities of Chromobacterium and Janthinobacterium ribosomal ribonucleic acid cistrons. Int. J. Syst. Bacteriol. 28: 154-168.

12. De Ley, J., P. Segers, K. Kersters, W. Mannheim, and A. Lievens. 1986. Intra- and intergeneric similarities of the Bordetella ribosomal ribonucleic acid cistrons: proposal for a new family, Alcaligenaceae. Int. J. Syst. Bacteriol. 36:405-414.

13. De Ley, J., and J. Van Muylem. 1963. Some applications of deoxyribonucleic acid base composition in bacterial taxonomy. Antonie van Leeuwenhoek J. Microbiol. Serol. 29:344-358.

14. De Smedt, J., M. Bauwens, R. Tytgat, and J. De Ley. 1980. Intraand intergeneric similarities of ribosomal ribonucleic acid cistrons of free-living nitrogen-fixing bacteria. Int. J. Syst. Bacteriol. 30:106-122.

15. De Vos, P., and J. De Ley. 1983. Intra- and intergeneric similarities of Pseudomonas and Xanthomonas ribosomal ribonucleic acid cistrons. Int. J. Syst. Bacteriol. 33:487-509.

16. De Vos, P., M. Goor, M. Gillis, and J. De Ley. 1985. Ribosomal ribonucleic acid cistron similarities of phytopathogenic Pseudomonas species. Int. J. Syst. Bacteriol. 35:169-184.

17. Edwards, R., and R. K. A. Feltham. 1983. Taxonomic implications of the cellular fatty acid content of the Legionellaceae and possibly related species. FEMS Microbiol. Lett. 17:251-255.

18. Elwell, L. P., and S. Falkow. 1977. Plasmids of the genus Neisseria, p. 137-154. In R. B. Roberts (ed.), The gonococcus. John Wiley \& Sons, Inc., New York.

19. Falsen, E. 1988. Catalogue of strains CCUG, Culture Collection, 5 th ed. University of Göteborg, Göteborg, Sweden.

20. Gillis, M., and J. De Ley. 1975. Determination of the molecular complexity of double-stranded phage genome DNA from initial renaturation rates. The effect of DNA base composition. J. Mol. 
Biol, 98:447-464

21. Gillis, M., and J. De Ley. 1980. Intra- and intergeneric similarities of the ribosomal ribonucleic acid cistrons of Acetobacter and Gluconobacter. Int. J. Syst. Bacteriol. 30:7-27.

22. Goldstein, E. J. C., and M. E. Gombert. 1983. Eikenella corrodens: a new perspective, p. 1-43. In E. J. Bottone (ed.), Unusual microorganisms. Gram-negative fastidious species. Marcel Dekker, Inc., New York.

23. Guibourdenche, M., M. Y. Popoff, and J. Y. Riou. 1986. Deoxyribonucleic acid relatedness among Neisseria gonorrhoeae, $N$. meningitidis, $N$. lactamica, $N$. cinerea and "Neisseria polysaccharea." Ann. Microbiol. (Paris) 137B:177-185.

24. Haug, R. H., and S. D. Henriksen. 1969. The serology of Moraxella kingii. Acta Pathol. Microbiol. Scand. 75:641-647.

25. Henriksen, S. D. 1969. Designation of the type strain of $\mathrm{Bac}$ teroides corrodens Eiken 1958. Int. J. Syst. Bacteriol. 19: 375-376.

26. Henriksen, S. D. 1969 . Corroding bacteria from the respiratory tract. II. Bacteroides corrodens. Acta Pathol. Microbiol. Scand. 75:91-96.

27. Hoke, C., and N. A. Vedros. 1982. Taxonomy of the neisseriae: deoxyribonucleic acid base composition, interspecific transformation, and deoxyribonucleic acid hybridization. Int. J. Syst. Bacteriol. 32:57-66.

28. Holmes, B., and M. S. Ahmed. 1981. Group EF-4: a Pasteurellalike organism, p. 161-174. In M. Kilian, W. Frederiksen, and E. L. Biberstein (ed.), Haemophilus, Pasteurella and Actinobacillus. Academic Press, Inc. (London), Ltd., London.

29. Hylemon, P. B., J. S. Wells, N. R. Krieg, and H. W. Jannasch. 1973. The genus Spirillum: a taxonomic study. Int. J. Syst. Bacteriol. 23:340-380.

30. Jackson, F. L., and Y. E. Goodman. 1972. Transfer of the facultatively anaerobic organism Bacteroides corrodens Eiken to a new genus, Eikenella. Int. J. Syst. Bacteriol. 22:73-77.

31. Jackson, F. L., and Y. Goodman. 1984. Genus Eikenella Jackson and Goodman 1972, 74 ${ }^{\mathrm{AL}}$, p. 591-597. In N. R. Krieg and J. G. Holt (ed.), Bergey's manual of systematic bacteriology, vol 1. The Williams \& Wilkins Co., Baltimore.

32. Jantzen, E., K. Bryn, T. Bergan, and K. Bøvre. 1974. Gas chromatography of bacterial whole cell methanolysates. V. Fatty acid composition of Neisseriae and Moraxellae. Acta Pathol. Microbiol. Scand. Sect. B 82:767-779.

33. Jantzen, E., K. Bryn, N. Hagen, T. Bergan, and K. Bøvre. 1978. Fatty acids and monosaccharides of Neisseriaceae in relation to established taxonomy. Nat. Inst. Public Health Ann. (Norway) 1:59-71.

34. Jantzen, E., O. M. Kvalheim, T. A. Hauge, N. Hagen, and K. Bøvre. 1987. Grouping of bacteria by simca pattern recognition on gas chromatographic lipid data: patterns among Moraxella and rod-shaped Neisseria. Syst. Appl. Microbiol. 9:142-150.

35. Jenkins, C. L., D. A. Kuhn, and K. R. Daly. 1977. Fatty acid composition of Simonsiella strains. Arch. Microbiol. 113:209213

36. Juni, E., and G. A. Heym. 1986. Psychrobacter immobilis gen. nov., sp. nov.: genospecies composed of gram-negative, aerobic, oxidase-positive coccobacilli. Int. J. Syst. Bacteriol. 36: 388-391.

37. Kingsbury, D. T. 1967. Deoxyribonucleic acid homologies among species of the genus Neisseria. J. Bacteriol. 94:870-874.

38. Kuhn, D. A. 1981. The genera Simonsiella and Alysiella, p. 390-399. In M. P. Starr, H. Stolp, H. G. Trüper, A. Balows, and H. G. Schlegel (ed.), The prokaryotes, vol. 1. Springer-Verlag, Berlin.

39. Kuhn, D. A., D. A. Gregory, G. E. Buchanan, Jr., M. D. Nyby, and K. R. Daly. 1978. Isolation, characterization, and numerical taxonomy of Simonsiella strains from the oral cavities of cats, dogs, sheep, and humans. Arch. Microbiol. 118:235-241.

40. Marmur, J. A. 1961. A procedure for the isolation of deoxyribonucleic acid from micro-organisms. J. Mol. Biol. 3:208-218.

41. Moss, C. W., P. L. Wallace, D. G. Hollis, and R. E. Weaver. 1988. Cultural and chemical characterization of CDC groups EO-2, M-5, and M-6, Moraxella (Moraxella) species, Oligella urethralis, Acinetobacter species, and Psychrobacter immobilis. J. Clin. Microbiol. 26:484-492.

42. Prefontaine, G., and F. L. Jackson. 1972. Cellular fatty acid profiles as an aid to the classification of "corroding bacilli" and certain other bacteria. Int. J. Syst. Bacteriol. 22:210-217.

43. Reichenbach, H. 1981. Taxonomy of the gliding bacteria. Annu. Rev. Microbiol. 35:339-364.

44. Richards, G. M. 1974. Modification of the diphenylamine reaction giving increased sensitivity and simplicity in the estimation of DNA. Anal. Biochem. 57:369-376.

45. Riou, J. Y., and M. Guibourdenche. 1987. Neisseria polysaccharea sp. nov. Int. J. Syst. Bacteriol. 37:163-165.

46. Riou, J. Y., M. Guibourdenche, and M. Y. Popoff. 1983. A new taxon in the genus Neisseria. Ann. Microbiol. (Paris) 134B: 257-267.

47. Rossau, R., K. Kersters, E. Falsen, E. Jantzen, P. Segers, A. Union, L. Nehls, and J. De Ley. 1987. Oligella, a new genus including Oligella urethralis comb. nov. (formerly Moraxella urethralis) and Oligella ureolytica sp. nov. (formerly CDC group IVe): relationship to Taylorella equigenitalis and related taxa. Int. J. Syst. Bacteriol. 37:198-210.

48. Rossau, R., A. Van Landschoot, W. Mannheim, and J. De Ley. 1986. Inter- and intrageneric similarities of ribosomal ribonucleic acid cistrons of the Neisseriaceae. Int. J. Syst. Bacteriol. 36:323-332.

49. Rubin, J. S., P. A. Granato, and B. L. Wasilauskas. 1985. Glucose-nonfermenting gram-negative bacteria, p. 330-349. In E. H. Lennette, A. Balows, W. J. Hausler, Jr., and H. J. Shadomy (ed.), Manual of clinical microbiology, 4th ed. American Society for Microbiology, Washington, D.C.

50. Snell, J. J. S. 1984. Kingella Henriksen and B $\phi$ vre 1976, $449^{\mathrm{AL}}$, p. 307-309. In N. R. Krieg and J. G. Holt, Bergey's manual of systematic bacteriology, vol. 1. The Williams \& Wilkins Co., Baltimore.

51. Snell, J. J. S., and S. P. Lapage. 1976. Transfer of some saccharolytic Moraxella species to Kingella Henriksen and B $\phi$ vre 1976, with descriptions of Kingella indologenes sp. nov. and Kingella denitrificans sp. nov. Int. J. Syst. Bacteriol. 26:451-458.

52. Stackebrandt, E. 1986. Das hierarchische System der Eubakterien: Problem und Lösungsansätze. Forum Mikrobiol. 9:255260

53. Van Landschoot, A., R. Rossau, and J. De Ley. 1986. Intra- and intergeneric similarities of the ribosomal ribonucleic acid cistrons of Acinetobacter. Int. J. Syst. Bacteriol. 36:150-160.

54. Vedros, N. A. 1984. Neisseria Trevisan $1885,105^{\mathrm{AL}}$, p. $290-296$. In N. R. Krieg and J. G. Holt (ed.), Bergey's manual of systematic bacteriology, vol. 1. The Williams \& Wilkins Co. Baltimore.

55. Vedros, N. A., C. Hoke, and P. Chun. 1983. Neisseria macacae sp. nov., a new Neisseria species isolated from the oropharynges of rhesus monkeys (Macaca mulatta). Int. J. Syst. Bacteriol. 33:515-520.

56. Weaver, R. E., D. G. Hollis, and E. J. Bottone. 1985. Gramnegative fermentative bacteria and Francisella tularensis, p. 309-329. In E. H. Lennette, A. Balows, W. J. Hausler, Jr., and H. J. Shadomy (ed.), Manual of clinical microbiology, 4th ed. American Society for Microbiology, Washington, D.C. 